\title{
O Kyrie de Nepomuceno: estilo e intertextualidade
}

Nepomuceno's Kyrie: style and intertextuality

Thiago Plaça Teixeira

Universidade Federal do Paraná (UFPR) - thiagoplacateixeira@gmail.com 


\section{Resumo}

O presente artigo apresenta uma análise do Kyrie da Missa em Ré menor (1915) de Alberto Nepomuceno (1864-1920), visando identificar características estilísticas e relações de intertextualidade musical. Quanto à forma, textura e timbre, o Kyrie de Nepomuceno apresenta grande semelhança com o Kyrie da Missa Te Deum laudamus (1899), de Lorenzo Perosi (1872-1956). Quanto à harmonia, a obra denota certo caráter modal, possivelmente por influência de técnicas de harmonização do canto gregoriano. Quanto à melodia e à prosódia, nota-se certa proximidade com as linhas melódicas gregorianas, consideradas então paradigma da música sacra católica.

Palavras-chave: Musicologia; Alberto Nepomuceno; Análise musical; Missa.

\section{Abstract}

This article presents an analysis of the Kyrie in Alberto Nepomuceno's Mass in $D$ minor (1915), one of the goals being to identify stylistic features and musical intertextual relations. In relation to form, texture and timbre, Nepomuceno's Kyrie presents great similarity to the Kyrie of Lorenzo Perosi, Missa Te Deum Laudamus (1899). As concerns harmony, the piece denotes a kind of modal character, possibly due to the organ techniques which accompany the gregorian chant. Regarding melody and prosody, there is a certain proximity to gregorian melodic contours, considered at the time as a paradigm of catholic church music.

Keywords: Musicology; Alberto Nepomuceno; Musical analysis; Mass. 


\section{Introdução}

O compositor brasileiro Alberto Nepomuceno (1864-1920), um dos mais importantes personagens da música nacional na passagem do século XIX ao XX, produziu um conjunto de obras que abarca diferentes gêneros, entre os quais o da tradicional música sacra coral católica. E, segundo Goldberg (2006), "uma das facetas mais ignoradas nos estudos sobre Alberto Nepomuceno diz respeito a sua produção sacra". No Catálogo ${ }^{1}$ das obras de Nepomuceno constam, como peças sacras, alguns motetos, algumas peças para voz e órgão/piano e uma Missa. Esta última é, sem dúvida, a peça religiosa de Nepomuceno de maior envergadura.

O título completo da Missa, conforme consta na sua edição da época, é Missa duabus vocibus aequalibus quam in honorem Virginis Immaculatae concinnavit et Eminentissimo Domino Cardinali Arcoverde dicavit, isto é, "Missa a duas vozes iguais composta em honra da Virgem Imaculada e dedicada ao Sr. Eminentíssimo Cardeal Arcoverde". Trata-se de uma obra que Nepomuceno dedicou ao então Cardeal Arcebispo do Rio de Janeiro, Dom Joaquim Arcoverde de Albuquerque Cavalcanti (1850-1930), por ocasião do seu Jubileu Episcopal, isto é, de seus 25 anos de Episcopado, celebrado com uma Missa Pontifical na Catedral do Rio de Janeiro em 26 de outubro de 1915, ocasião esta em que a Missa de $\mathrm{Ne}$ pomuceno foi executada pela Schola Cantorum Santa Cecília, sob a regência do Cônego Pe. Alpheu Lopes de Araújo?.

Considerando-se a formação europeia de Nepomuceno, que incluiu um período na Schola Cantorum de Paris, a sua atuação em prol da regulamentação da música sacra na arquidiocese do Rio de Janeiro na década de 1890-99 e sua ativa participação na recuperação da obra sacra do compositor brasileiro Pe. José Maurício Nunes Garcia (1767-1830), é de se esperar que suas composições sacras, e particularmente a sua Missa, reflita de algum modo as exigências estéticas inerentes à produção musical eclesiástica da época. Ora, é notório que neste período, entre o final do século XIX e as primeiras décadas do século $\mathrm{XX}$, há dois fatores determinantes para a música sacra católica: o movimento chamado Cecilianismo e a preocupação das autoridades da Igreja em regular/restaurar a música litúrgica tradicional, sobretudo o canto gregoriano e a polifonia no estilo de $\mathrm{Pa}$ lestrina (1525-1594).

No presente artigo, dedicamo-nos a analisar musicalmente a primeira unidade funcional $^{3}$ da referida Missa de Nepomuceno, o Kyrie. Ao definirmos a presente abordagem dentro do âmbito de estilo e intertextualidade, procuramos justamente orientar a análise para aqueles procedimentos compositivos que auxiliem a compreender a relação da obra de Nepomuceno com outros compositores ou com algum paradigma predefinido. Por estilo, entende-se "uma replicação de modelos, tanto no comportamento humano como nos artefatos produzidos pelo homem, que resulta de uma série de escolhas realizadas dentro de um campo de restrições" (MEYER, 1996, p. 3, tradução nossa). Ou seja,

\footnotetext{
1 Cf. CORREA, 1996.

2 Cf. O Paiz, Rio de Janeiro, 27/10/1915.

3 Cf. CASTAGNA, 2004.
} 
analisar o estilo de uma obra significa investigar, de certa forma, a lei interna que rege tal obra. Por intertextualidade, termo oriundo da crítica literária, entende-se o âmbito de modos como uma obra musical pode referir-se ou modelar-se a outras obras musicais (BURKHOLDER, 2001).

Assim, pois, pretende-se analisar a estrutura interna do Kyrie de Nepomuceno, mas também a sua relação com outras obras, principalmente levando-se em conta o repertório que era colocado na época como paradigma estético para a música sacra católica.

\section{O tema introdutório do Kyrie}

Um dos elementos característicos da Missa de Nepomuceno é a múltipla utilização de um tema melódico para solo de órgão. Trata-se de três compassos 3/4 em que a melodia é apresentada em oitava: partindo do Ré, sobe-se até o Si bemol por graus conjuntos, desce-se um semitom até o Lá e, em seguida, faz-se uma curva melódica descendo-se até o Mi e voltando-se ao Lá, configurando um prolongamento melódico de tal nota (Fig. 1).

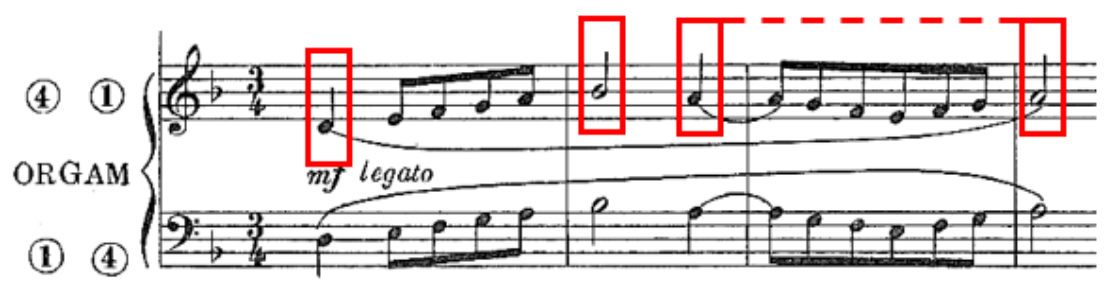

Fig. 1 - Nepomuceno: solo de órgão introdutório na Missa (NEPOMUCENO, s.d.).

Este tema aparece em diferentes momentos da obra:

- No início do Kyrie, como introdução geral à Missa, e, como breve interlúdio, após o Christe eleison;

- No início do Gloria, como introdução, e, como breve interlúdio, antes do trecho final Quoniam tu solus sanctus;

- No início do Credo, como introdução, e no Amen final cantado em uníssono pelas duas vozes;

- No início do Agnus Dei, como introdução, com escrita a 4 vozes; como breve interlúdio, após o segundo Qui tollis peccata mundi; e, finalmente, como encerramento geral da Missa.

A recorrência do tema e a posição estratégica (introdução, encerramento ou interlúdio) em que é colocado ao longo das unidades funcionais da Missa indica que se trata de algo relevante para a estruturação da obra. $O$ fato, porém, de que Nepomuceno opte por uma simples linha melódica em oitavas ao órgão dentro dos limites de uma 6a menor parece-nos indicar uma intenção do compositor em inserir em sua composição um elemento musical que remeta ao cantochão tradicional. Com efeito, o desenho 
melódico ascendente Ré-Lá seguido da $2^{\mathrm{a}}$ menor descendente Si bemol-Lá é uma das melodias típicas do Modo I (Protus ou Dórico). Giulio Bas (1874-1929), por exemplo, em seu método para acompanhamento do canto gregoriano (BAS, [1913] 1947, p. 31), indica duas figuras melódicas que, em conexão, configuram o Modo I gregoriano (Fig. 2).

I

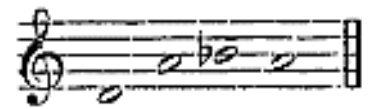

Fig. 2 - Elementos melódicos característicos do Modo I (BAS, 1923, p. 31)

Também Paolo Ferretti (1866-1938) indica esta figura melódica como uma das fórmulas de entoação típicas do Modo I (Fig. 3).

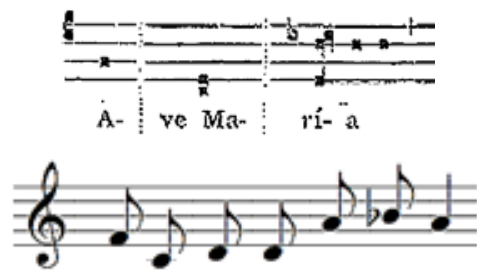

Fig. 3 - Elementos melódicos característicos do Modo I (FERRETTI, 1934, p. 118).

Diversas são as peças gregorianas escritas no Modo I que, de fato, iniciam-se com tal figura (ou alguma variação dela). Nos diversos versos do Invitatório do Ofício de Matinas do Natal (Fig. 4), o salto Ré-Lá seguido por Si bemol-Lá é constante em todos os inícios. Curiosamente, a antífona de tal Invitatório, repetida após cada verso, inicia-se com a sequência melódica ascendente Ré-Lá, preenchida por grau conjunto, semelhantemente ao que se encontra na Introdução de Nepomuceno (Fig. 5). Pode-se encontrar a figura Ré-Lá-Si bemol-Lá também no início dos Introitos do Domingo dentro da Oitava de Corpus Christi e no Graduale da Festa do Sagrado Coração de Jesus (Fig. 6).

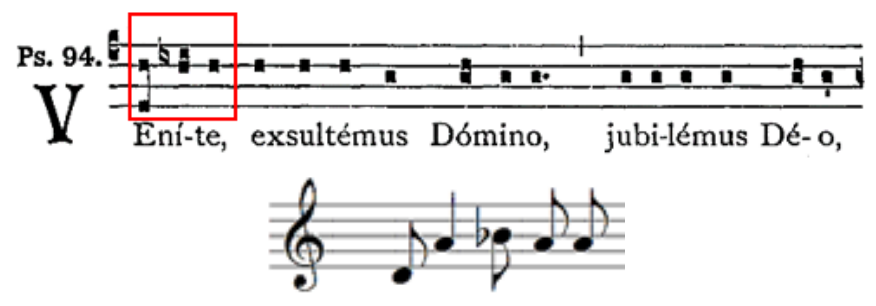

Fig. 4 - Canto Venite, exsultemus Domino (Liber Usualis, 1961, p. 368).
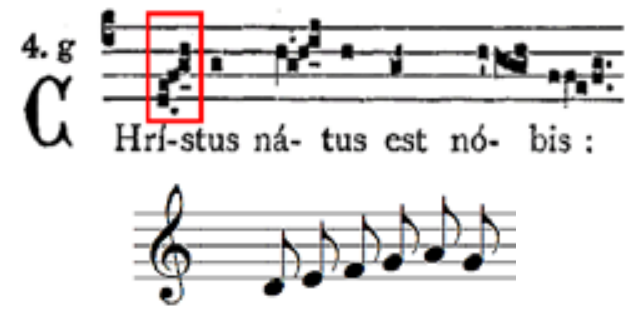

Fig. 5 - Antífona Christus natus est nobis (Liber Usualis, 1961, p. 368). 


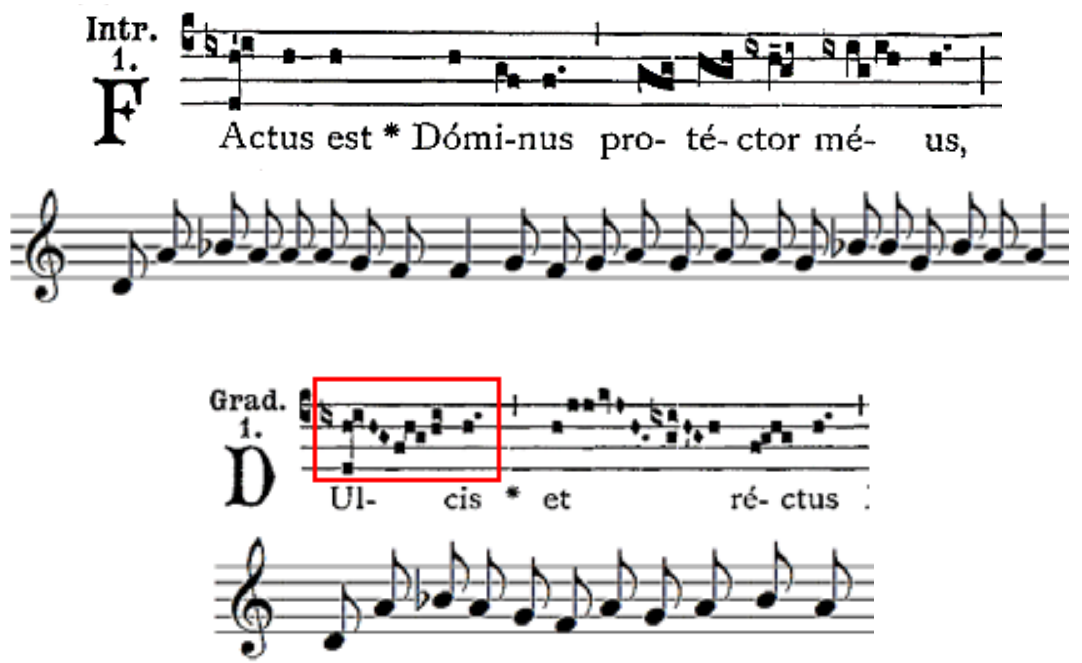

Fig. 6 - Utilização da Figura Ré-Lá-Si bemol-Lá em diversos cantos (Liber Usualis, 1961, p. 961).

No Alleluia da Missa de 8 de Dezembro, Festa da Imaculada Conceição da Bem-aventurada Virgem, encontra-se um desenho melódico igualmente semelhante àquele utilizado na Introdução de Nepomuceno ${ }^{4}$. Já no primeiro Alleluia, a melodia tem seu limite inferior no Ré e o superior na 6 ${ }^{\text {a }}$ menor acima, Si bemol. Partindo do Ré, a melodia sobe até sol, retorna à nota inicial e, em seguida, sobe à nota mais aguda. A finalização é em Lá, após uma breve volta melódica por grau conjunto entre Si bemol e o Fá inferior. No verso aleluiático - Tota pulchra - encontra-se novamente um contorno melódico muito semelhante (Fig. 7).

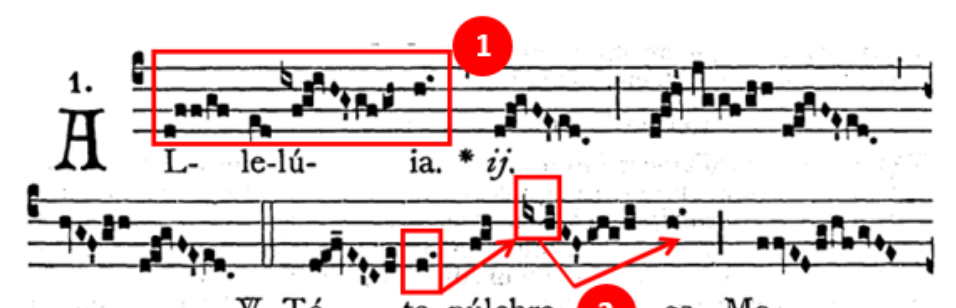

\. Tó- ta púlchra 2 es, Ma-

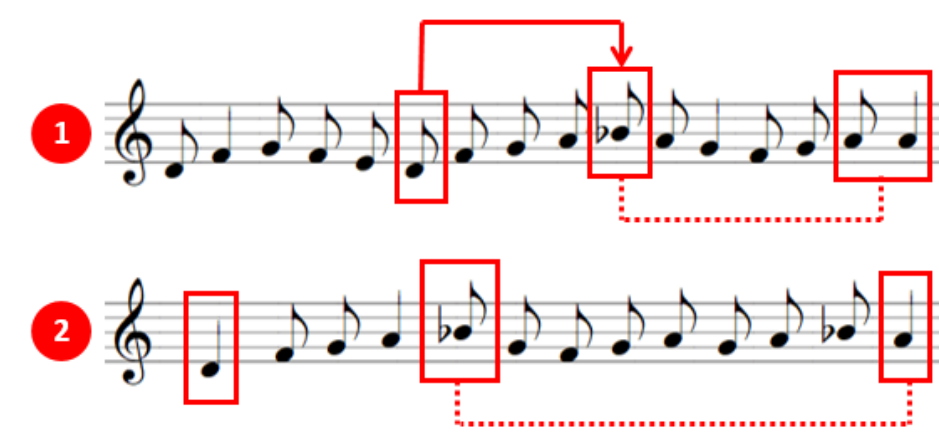

Fig. 7 - Alleluia Tota pulchra (Liber Usualis, 1961, p. 1318).

$4 \quad$ Foi na Festa da Imaculada Conceição (08 de dezembro) de 1914 que Nepomuceno assinou sua Missa e daí decorre certamente a dedicação da obra à Virgem Imaculada, tal como expresso no título oficial da obra. 
Em outra liturgia de importante festa mariana, a Assunção da Bem-aventurada Virgem Maria, em 15 de agosto, encontra-se igualmente a tradicional figura Ré-Lá-Si bemol na Antífona Quæ est ista, do Benedictus do Ofício de Laudes. Destaque-se que neste trecho tem-se uma breve pausa entre o Si bemol e o Lá imediatamente inferior (traço vertical na pauta e asterisco no texto), o que dá uma duração maior na execução do referido Si bemol, de modo semelhante à Introdução de Nepomuceno. No trecho seguinte tem-se novamente a volta melódica (descida do Lá até uma nota e retorno ao Lá), mas neste caso tem-se a descida melódica até o Mi, ou seja, no mesmo âmbito empregado por Nepomuceno (Fig. 8).

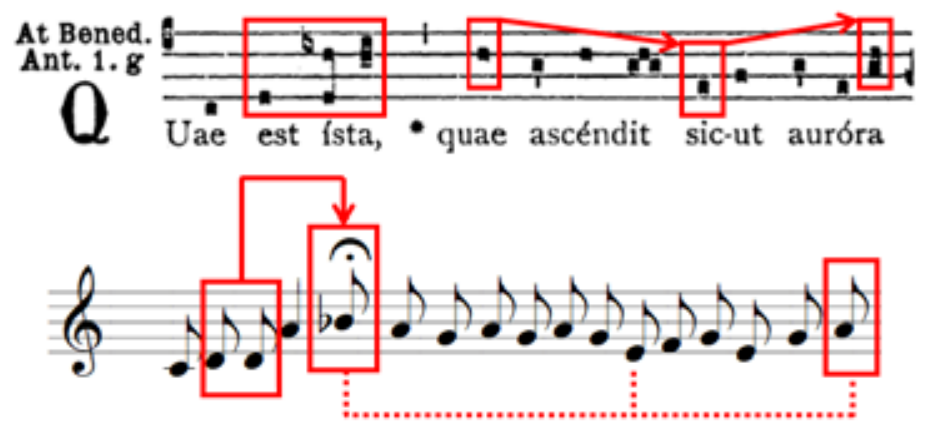

Fig. 8 - Antífona Quæ est ista (Liber Usualis, 1961, p. 1600).

Por sua vez, no Alleluia da Missa do Domingo dentro da Oitava da Ascensão, a figura Ré-Lá-Si bemol-Lá seguida por linha descendente inferior por grau conjunto seguida de retorno ao Lá é utilizada diversas vezes. Em pelo menos duas vezes a nota inferior do contorno melódico em torno do Lá é o Mi, tal como na Introdução de Nepomuceno (Fig. 9).

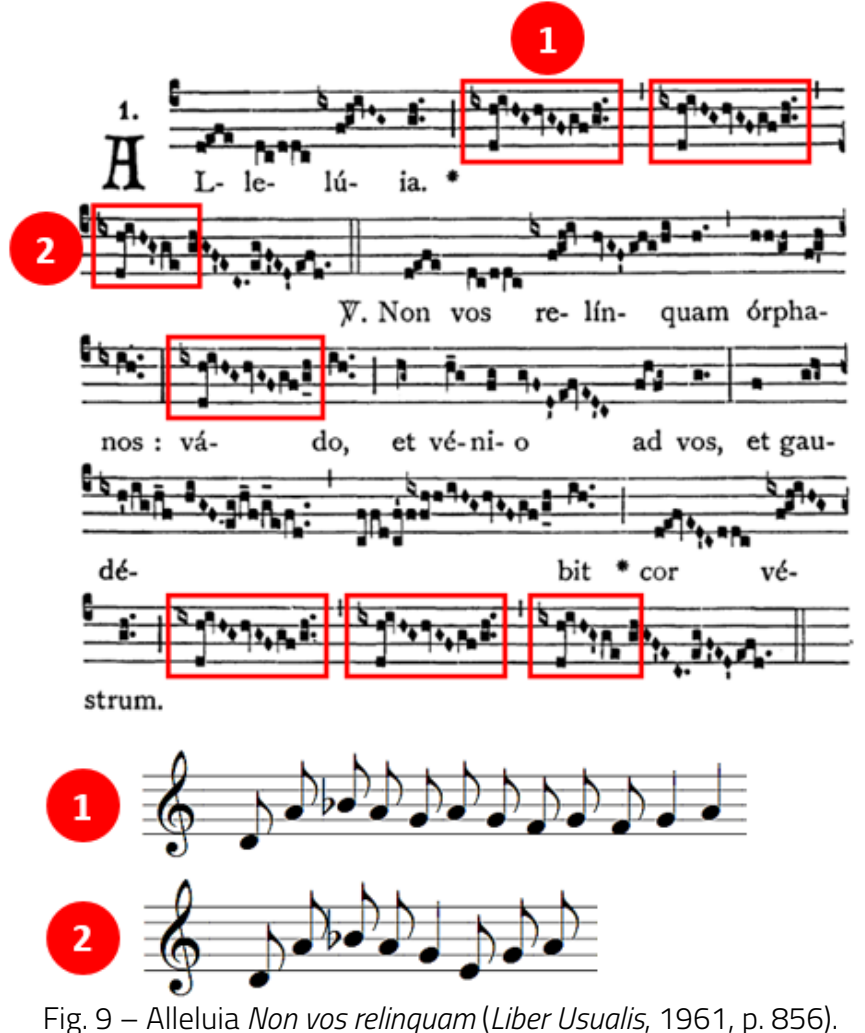


A nota Mi como limite inferior da volta melódica que sucede ao motivo Ré-Lá-Si bemol é encontrada também em partes do Ordinário das Missas no cantochão tradicional, tal como ocorre no Kyrie III, por exemplo, que apresenta 1) a figura Ré-Lá-Si bemol-Lá, 2) a descida até o Mi e 3) a ornamentação por grau conjunto em torno da nota Lá, dominante do modo (Fig. 10).

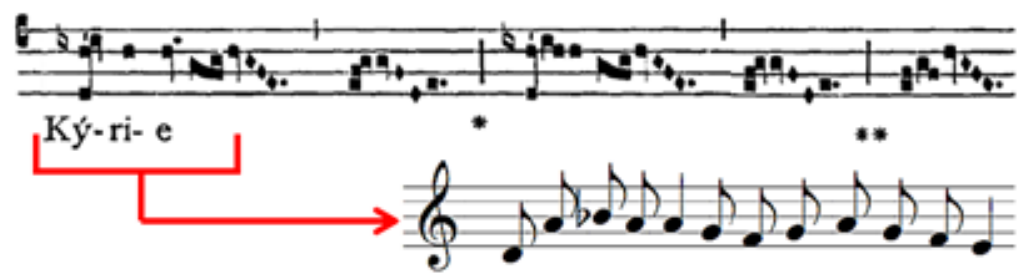

Fig. 10 - Kyrie III (Liber Usualis, 1961, p. 22-23).

Que as notas empregadas por Nepomuceno em sua Introdução, bem como o contorno melódico que lhes imprimiu, configurem, de fato, uma melodia caracteristicamente de sabor gregoriano e, portanto, apta a conferir uma certa simbologia religiosa às composições modernas, também se depreende por alguns exemplos de utilização semelhante de tema gregoriano em outras composições do século XIX-XX.

Tema similar é utilizado por Franz Liszt (1811-1886), por exemplo, em sua principal obra religiosa, o Oratório Christus (1862-1866). O início da obra se dá com uma Introdução orquestral baseada sobre o cantochão Rorate Caeli, intróito do 4음omingo do Advento. A escolha da melodia certamente se deve ao texto do canto gregoriano: "Rorate, cæli, désuper, et nubes pluant justum: aperiátur terra, et gérminet Salvatórem" ["Derramai, ó Céus, das alturas o vosso orvalho e que as nuvens chovam o Justo; abra-se a terra, e brote o Salvador"]. Trata-se de um trecho do Livro de Isaías $(45,8)$ que se refere explicitamente ao nascimento do Messias. Liszt insere a melodia gregoriana como marco inicial da primeira parte de seu Oratório, justamente como evocativa do iminente nascimento de Cristo, que será o tema dos seguintes quatro movimentos da obra, em um dos quais, aliás, Liszt utilizará novamente o mesmo tema. Quando ocorre na Introdução, o cantochão constitui-se em uma verdadeira citação, haja vista que Liszt respeita inclusive a estrutura rítmica original do canto, conforme se encontra na versão que ele possuía do Graduale Romanum ${ }^{5}$. A importância de tal tema gregoriano é ainda destacada pelo fato de Liszt utilizá-lo como sujeito para uma estrutura fugada (Fig. 11, 12 e 13).

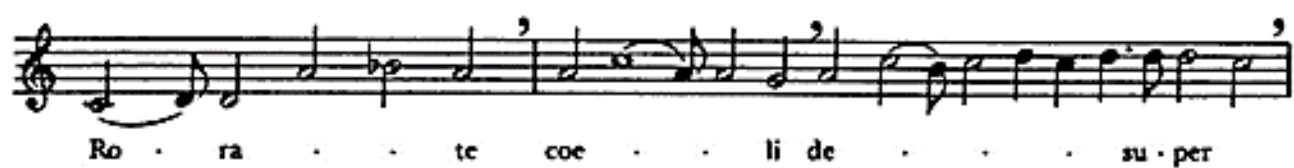

Fig. 11 - Canto Rorate cæli no Graduale Romanum de Liszt (MERRICK, [1987] 2008, p. 188). 


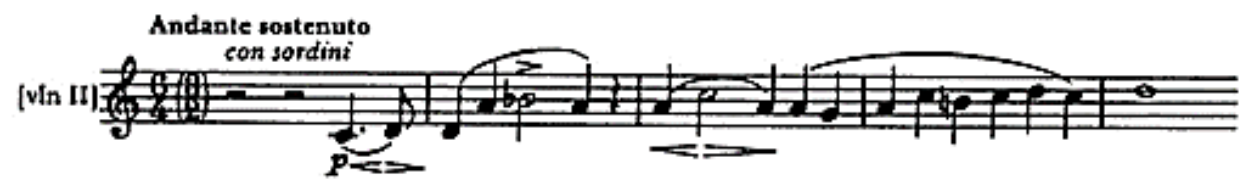

Fig. 12 - Liszt: melodia do Rorate cæli gregoriano na Introdução de Christus (MERRICK, 1987, p. 188).

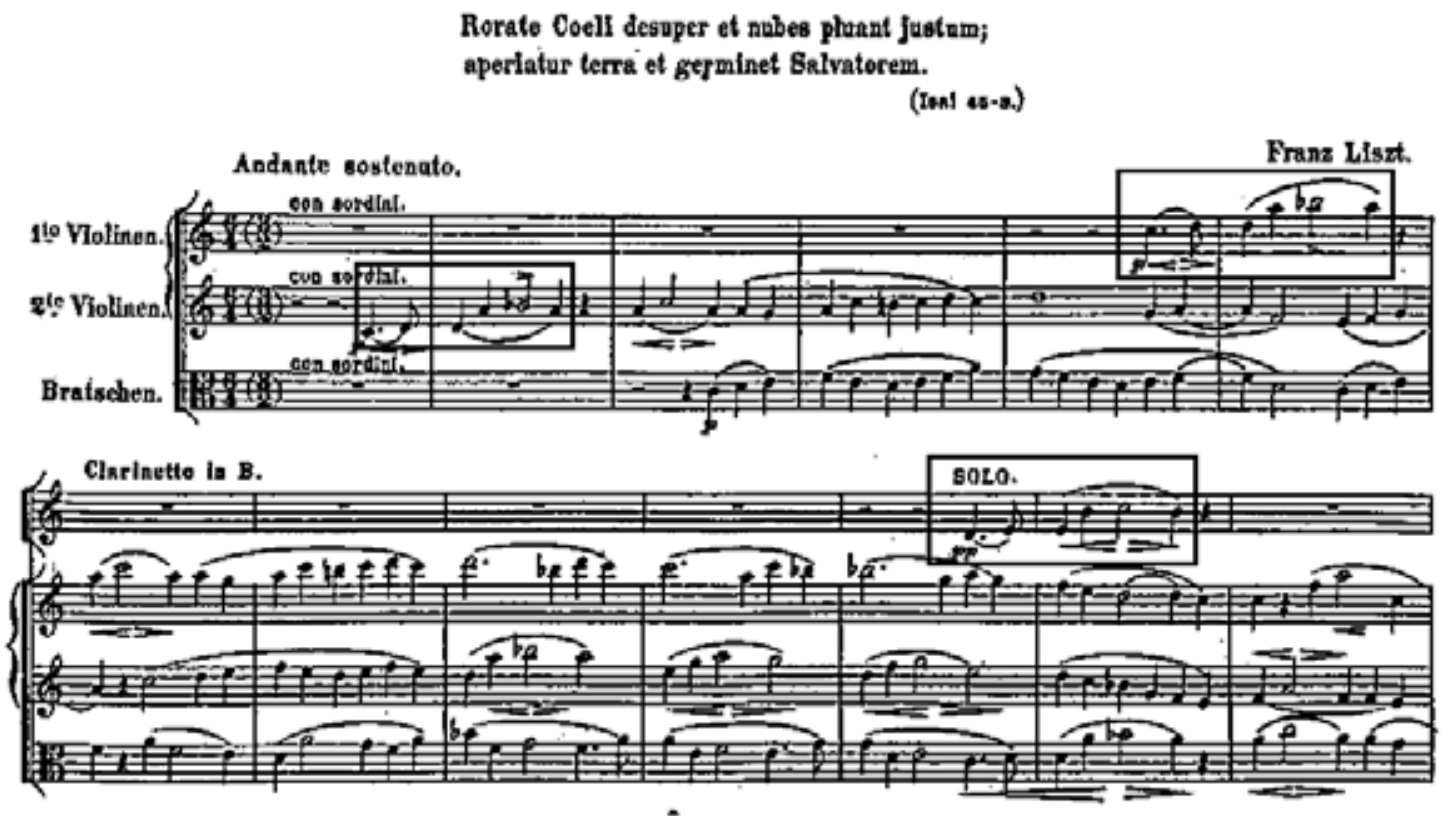

Fig. 13 - Liszt: melodia do Rorate cæli na Introdução de Christus (LISZT, 1872).

Assim, pois, pode-se apontar que a Introdução da Missa de Nepomuceno é construída com um perfil melódico caracteristicamente gregoriano. Pode-se também considerar que tal decisão compositiva deva-se ao ideal estético cecilianista de tomar como modelo supremo de música católica o cantochão medieval. O compositor brasileiro, portanto, apropria-se livremente de uma figuração melódica do tradicional canto litúrgico católico e o insere em sua obra como elemento de unidade e, de certa forma, como distintivo sonoro religioso.

Finalmente, deve-se dizer que a recorrência do tema de órgão introdutório ao longo das demais unidades funcionais da Missa não é um procedimento original de Nepomuceno. Na verdade, coincide exatamente com aquele empregado por Lorenzo Perosi (1872-1956) ${ }^{6}$, um dos mais importantes compositores de música sacra de sua época, em uma de suas Missas também a duas vozes: a Missa Te Deum laudamus, de 1899. Trata-se aqui, contudo, não de uma simples linha melódica de sabor gregoriano, como em

\footnotetext{
6 Perosi nasceu em Tortona, na Itália, em 1872 e morreu em Roma, em 1956. Iniciou seus estudos musicais com seu pai, Giuseppe Perosi (1849-1908), que era Maestro di Cappela da Catedral de Tortona. Estudou com Michele Saladino no Conservatório de Milão, onde diplomou-se em 1892. Após seus estudos em Milão, passou um ano de estudo na Kirchenmusikschule, em Regensburg, na Alemanha, com Franz Xaver Haberl, grande musicólogo, pioneiro editor das obras de Palestrina e Lassus. Em seguida, assumiu o trabalho de professor e diretor de música sacra em Imola, na Itália, entre 1892 e 1894, ano em que visitou a famosa Abadia de Solesmes, na França, onde estudou canto gregoriano com Dom Mocquereau e Dom Pothier. Entre 1894 e 1907, Perosi assumiu o cargo de Maestro da Capella Marciana na Basílica de São Marcos em Veneza, cujo então Patriarca era Dom Giuseppe Sarto, futuro Papa São Pio X, com quem Perosi cultivou grande amizade e por quem foi ordenado Sacerdote em 1895. Em 1898, Perosi foi indicado para o posto de Maestro Perpetuo della Capela Sistina, no Vaticano, cargo que manteve, ainda que com algumas interrupções, até sua morte, em 1956. Particularmente famoso por seus Oratórios, Perosi também compôs várias Missas e obras sacras menores, além de música secular, como, por exemplo, concertos e peças para música de câmara (Cf. CIAMPA, 2006).
} 
Nepomuceno, mas, sim, de um tema com a extensão de 3 compassos contruído como uma linha melódica descendente $(\wedge 3-\wedge 2-\wedge 1)$ com bordaduras, escrito na tradicional forma polifônica a 4 vozes. O próprio compositor indica na partitura este trecho como um Tema (Fig. 14).

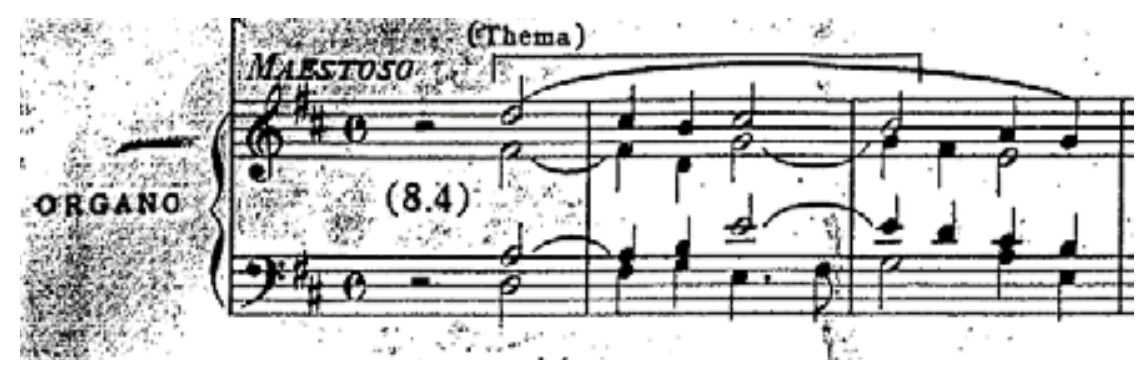

Fig. 14 - Perosi: introdução da Missa Te Deum laudamus (PEROSI, 1899).

Nepomuceno emprega sua Introdução no início do Kyrie (compassos 1 a 5) e, ainda na mesma unidade funcional, novamente após o Christe eleison (compassos 34 a 37), executado por cantor solista, como preparação ao último Kyrie eleison, executado pelo coro completo a duas vozes (Fig. 15a). É exatamente o mesmo procedimento compositivo utilizado por Perosi: após o uso do Tema como Introdução, ele volta a aparecer após o Christe eleison (compassos 24 a 26), o qual também é executado por cantor solista (Fig. 15b).
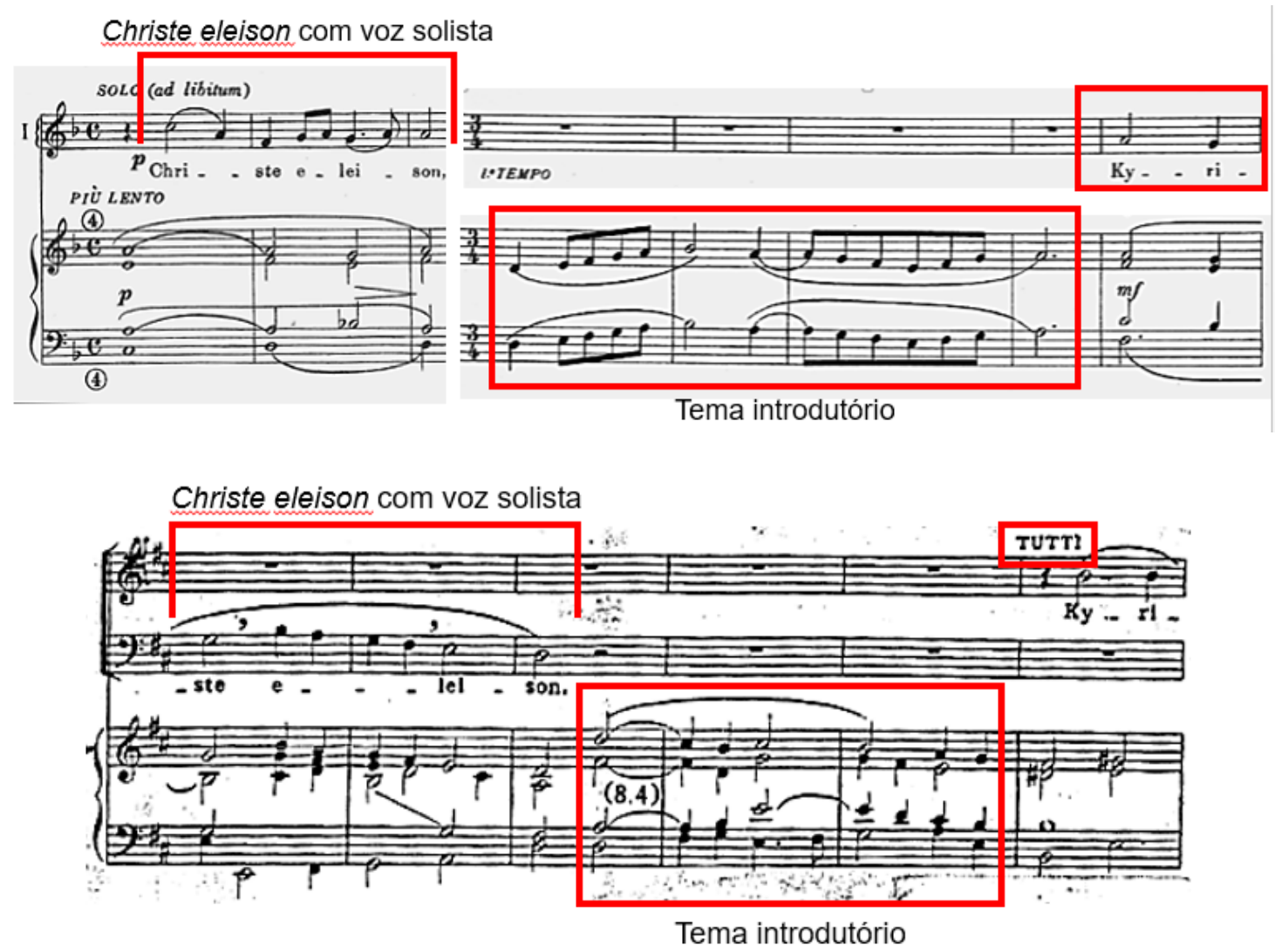

Fig. 15 - Tema de órgão como interlúdio dos Kyries de Perosi e de Nepomuceno (PEROSI, 1899; NEPOMUCENO, s.d.). 
No Gloria de Nepomuceno, o tema inicial para órgão é empregado no início, após a entoação do Gloria in excelsis Deo (feita pelo celebrante), imediatamente antes da entrada do Coro em Et in terra (Fig. 16a). Tal como no Kyrie, o compositor volta a utilizar a melodia inicial em outro trecho. Desta vez, imediatamente antes da entrada do Coro em Quoniam tu solus sanctus (compassos 93 a 95) (Fig. 16b). Uma variação temática da melodia do solo de órgão introdutório aparece também no Amen final. Ambas as vozes cantam em uníssono a subida melódica Ré-Lá por grau conjunto, mas em modo maior (Fig. 16c). Perosi, por sua vez, na Missa Te Deum laudamus, utiliza procedimento bastante semelhante. Primeiramente, emprega a mesma introdução com solo de órgão também no início do Gloria, antes do Coro entrar em Et in terra (Fig. 17a). Em segundo lugar, também utiliza o tema introdutório em outro trecho. Diferentemente de Nepomuceno, contudo, Perosi o insere mais ao final da unidade funcional, imediatamente antes de Cum Sancto Spiritu, e com a particularidade de transpor o tema para o v grau (Fá\# menor) (Fig. 17b).

a:

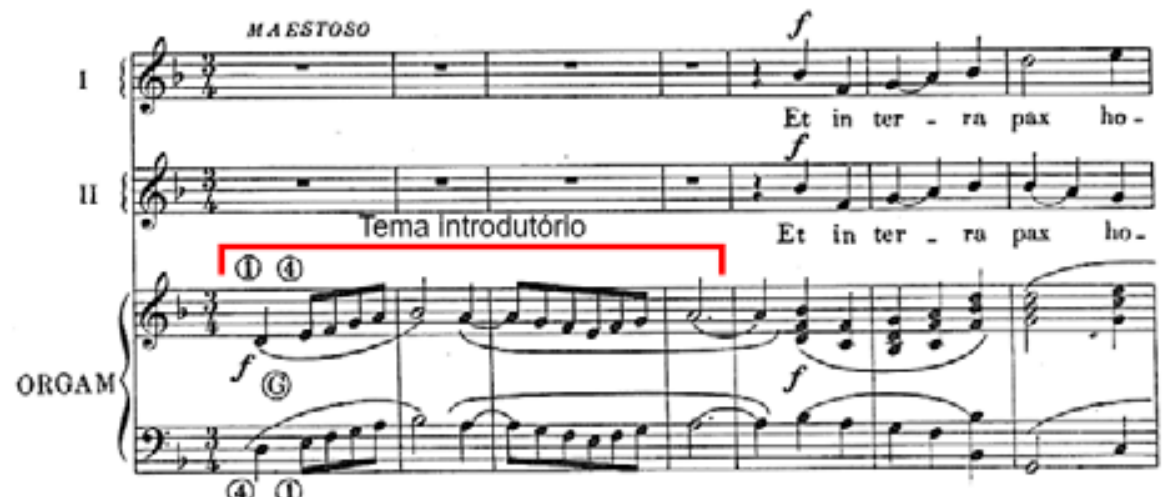

(4) (1)

b:

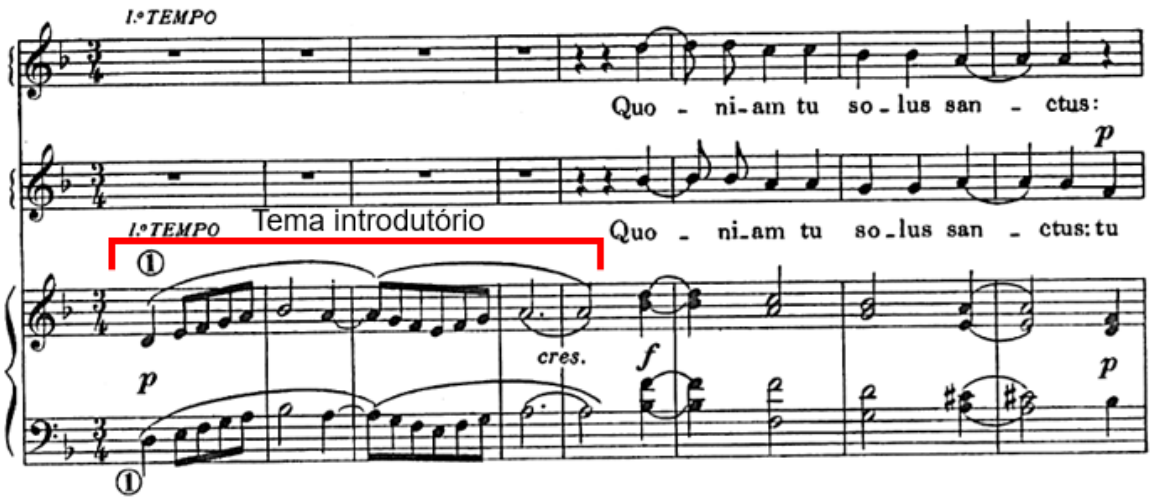

$1^{\text {a }}$ parte do Tema introdutório

c:

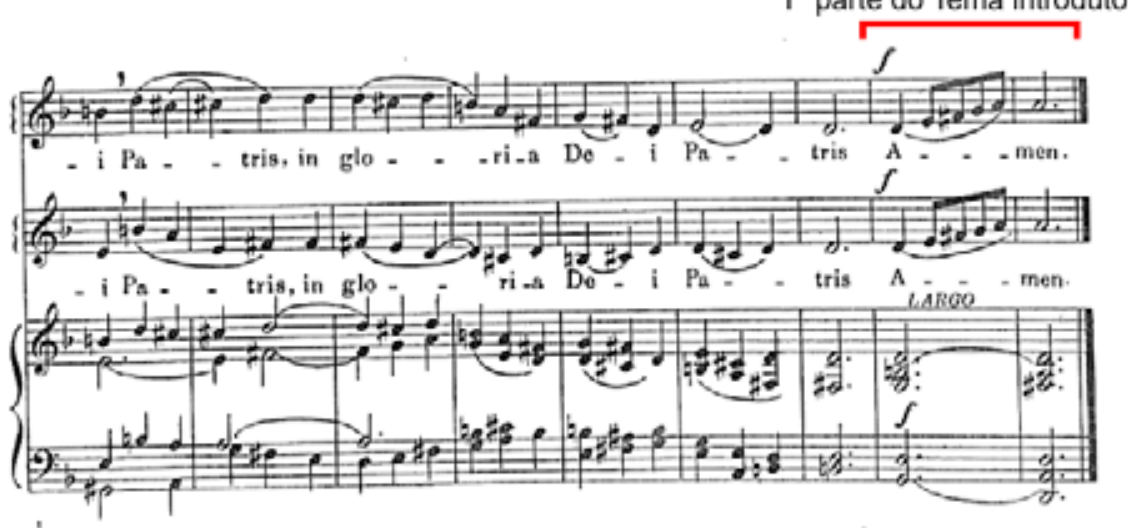

Fig. 16 - Nepomuceno: tema de órgão como introdução, interlúdio e final do Gloria (NEPOMUCENO, s.d.). 
a:

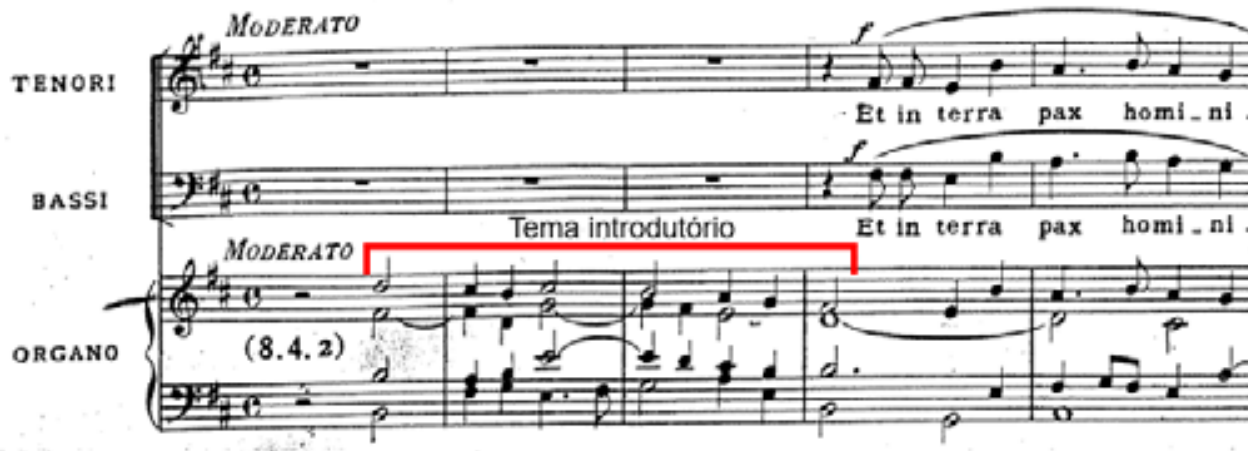

b:

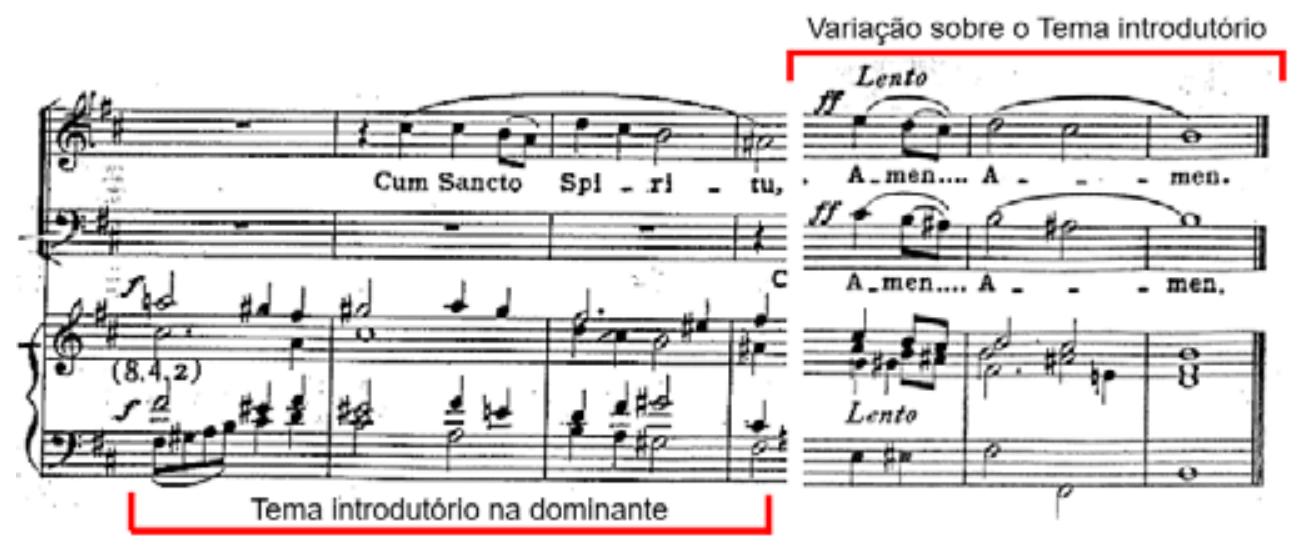

Fig. 17 - Perosi: tema de órgão como introdução, interlúdio e final do Gloria (PEROSI, 1899).

No Credo de Nepomuceno, o tema inicial para órgão é empregado novamente no início, após a entoação do Credo in unum Deum (feita pelo celebrante), imediatamente antes da entrada do Coro em Patrem omnipotentem (Fig. 18a). O tema aparece novamente por inteiro no Amen final, executado, contudo, em uníssono pelo órgão e as duas vozes do Coro (Fig. 18b). Perosi, na Missa Te Deum laudamus, também utiliza o mesmo tema introdutório do Kyrie e do Gloria no início do Credo (Fig. 19a). Volta a empregá-lo, transposto para o v grau (Fá\# menor) ao final, antes de Et vitam venturi sæculi, e no Amen final utiliza um desenho melódico semelhante ao tema inicial (Fig. 19b).

a:

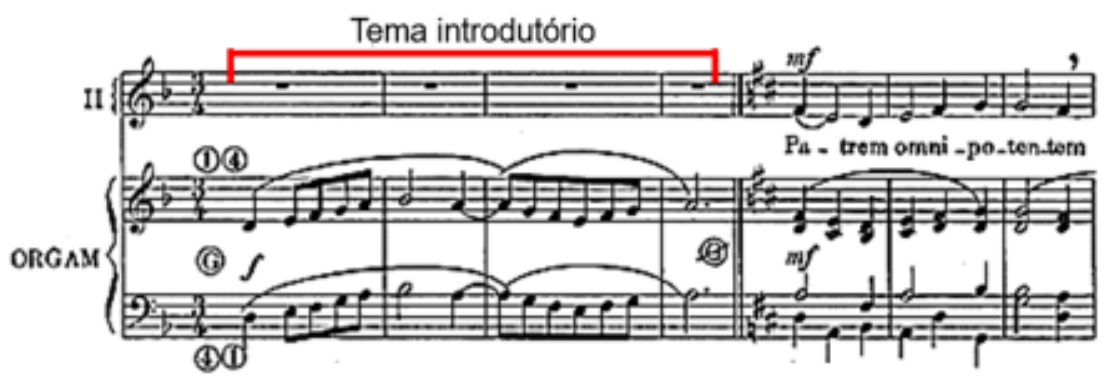


b:

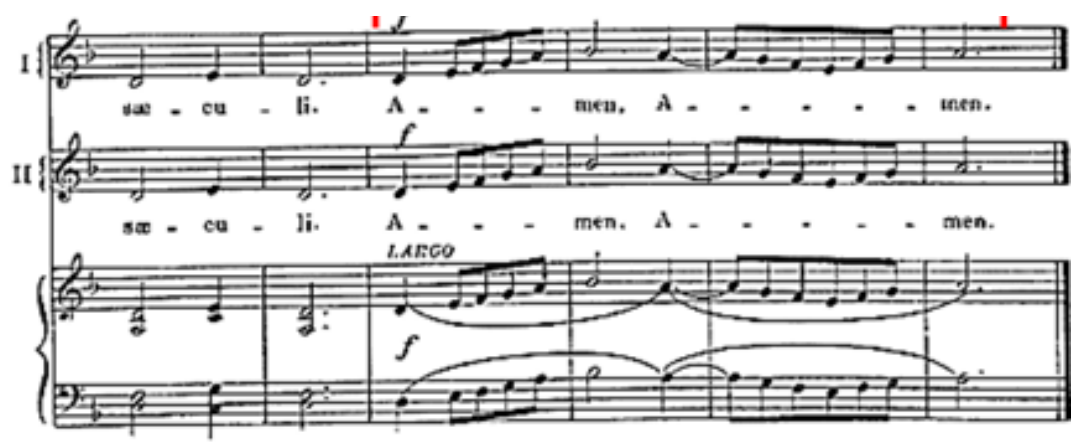

Fig. 18 - Nepomuceno: tema de órgão como introdução e final do Credo (NEPOMUCENO, s.d.).

a:

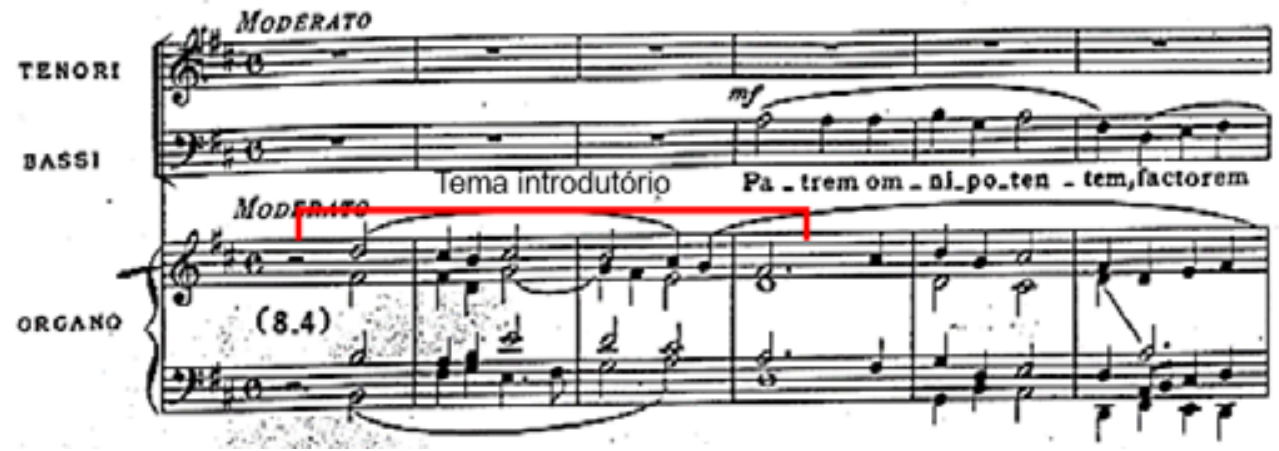

b:

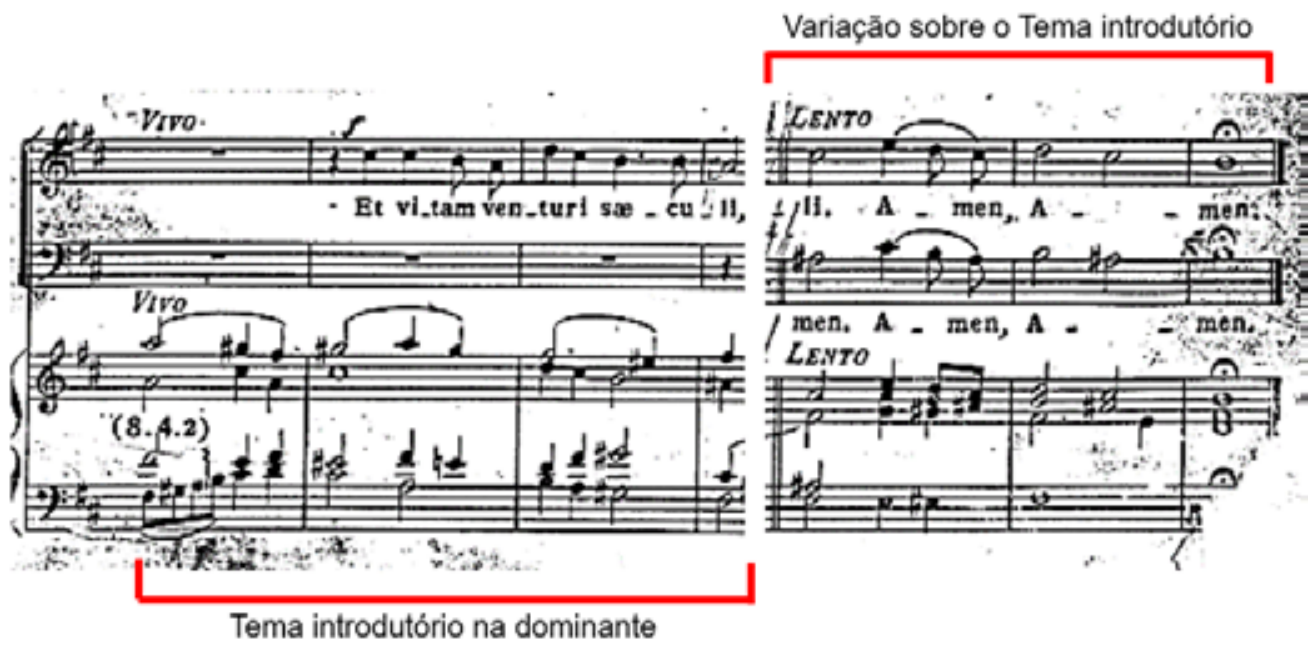

Fig. 19 - Perosi: tema de órgão como introdução e final do Credo (PEROSI, 1899).

No Sanctus-Benedictus, Perosi utiliza o seu mesmo tema inicial para órgão, mas com a peculiaridade de colocá-lo em meio a uma escrita contrapontística. A melodia principal, destacada como voz superior no Kyrie, no Gloria e no Credo, aqui aparece como Contralto. Na Missa de Nepomuceno, o Sanctus-Benedictus é a única unidade funcional da Missa em que o compositor não utiliza o tema inicial para órgão. No início do Agnus Dei, por sua vez, Nepomuceno insere o tema com uma variação na textura, semelhantemente ao procedimento de Perosi no seu Sanctus. Ao invés da recorrente 
escrita em uníssono, Nepomuceno opta pela escrita a quatro vozes, ainda que mantendo nas vozes superiores a melodia principal utilizada nas unidades anteriores (Fig. 20a). O tema volta a ser executado pelo órgão nos compassos 33 a 35, como preparação do terceiro Agnus Dei cantado pelo coro (Fig. 20b). Também é utilizado como encerramento da referida unidade funcional (e da Missa) nos compassos 55 a 58, como solo de órgão (Fig. 20c). Perosi faz o mesmo procedimento, utilizando três vezes o seu tema introdutório para órgão: 1) no início do Agnus Dei (Fig. 21a), 2) antes do terceiro Agnus Dei cantado pelo Coro (transposto para Fá\# menor) (Fig. 21b) e 3) ao final, como solo de órgão (Fig. 21c).

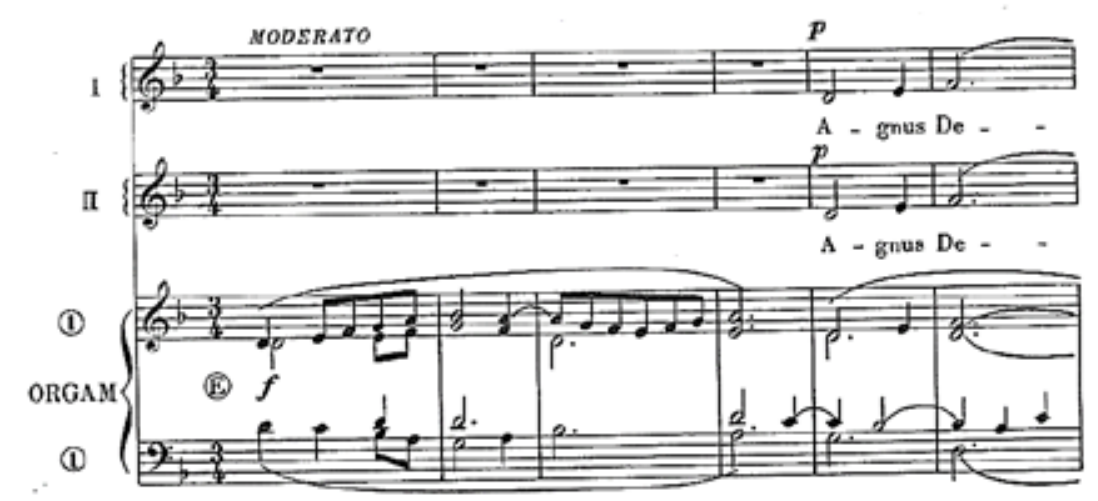

b:

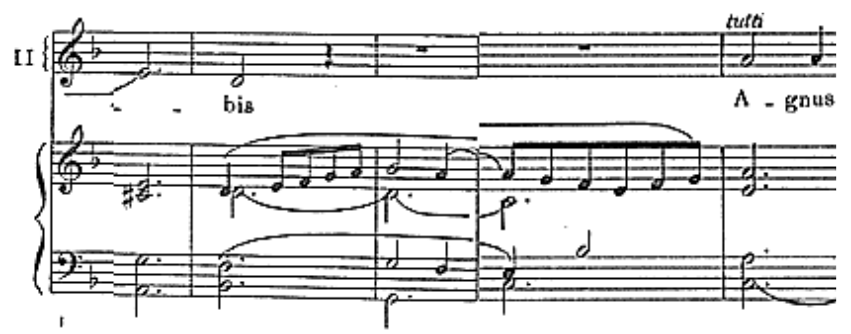

c:

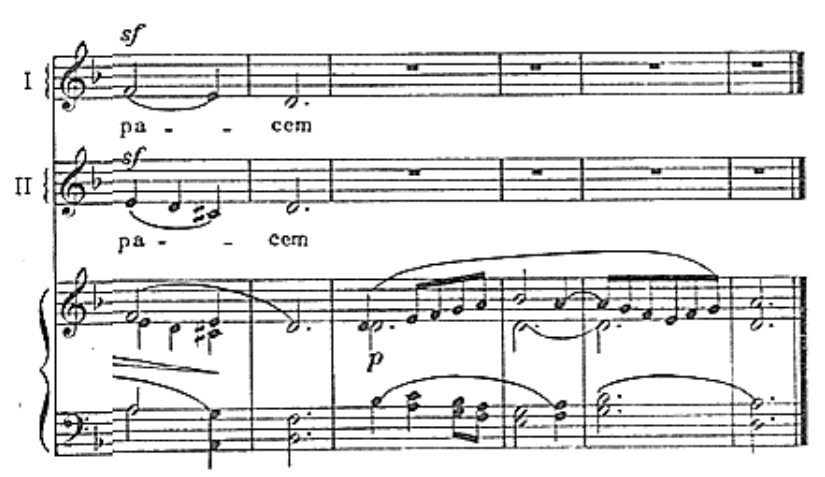

Fig. 20 - Nepomuceno: tema de órgão três vezes no Agnus Dei (NEPOMUCENO, s.d.). 
a:

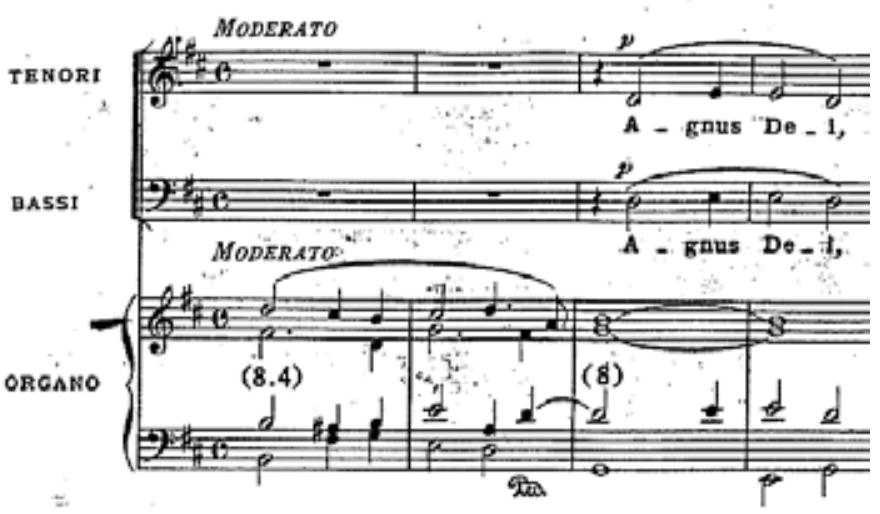

b:

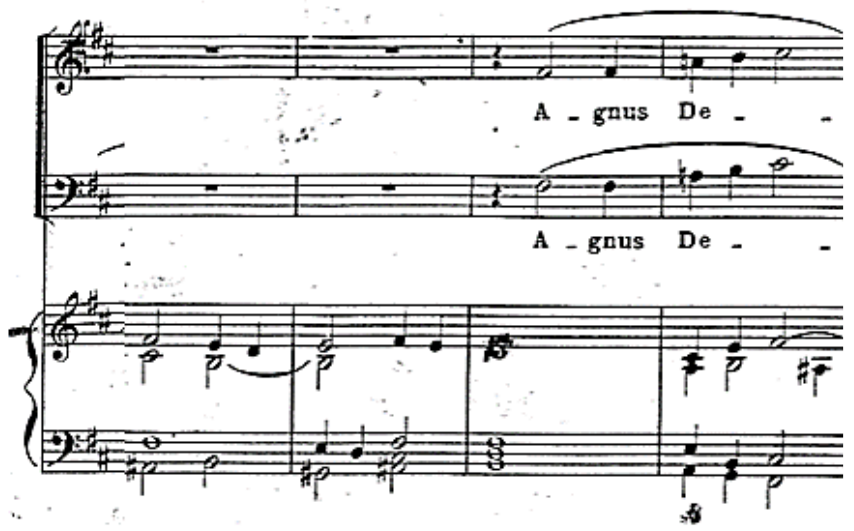

c:

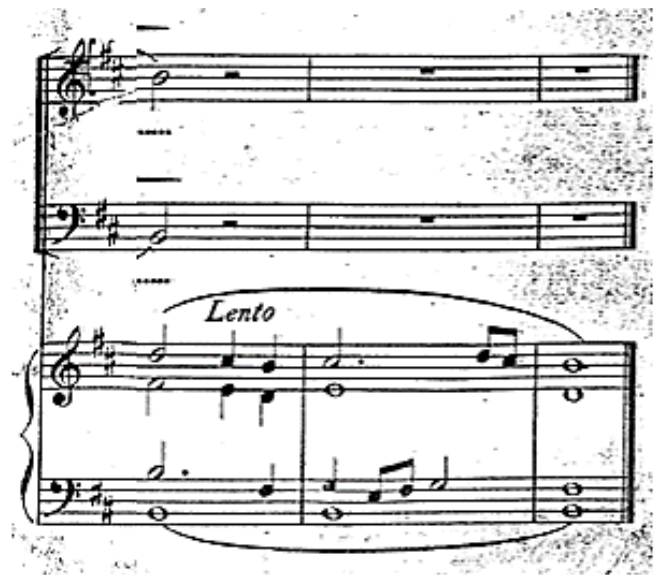

Fig. 21 - Perosi: tema de órgão três vezes no Agnus Dei (PEROSI, 1899).

Portanto, verifica-se que a utilização de um tema introdutório para órgão solista como elemento recorrente ao longo de todas as unidades funcionais da Missa, não só como introdução, mas também como interlúdios e póslúdios, é um procedimento encontrado tanto na Missa de Nepomuceno como na Missa Te Deum laudamus de Perosi (Tab. 1). No caso de Perosi, não se trata, contudo, de um procedimento recorrente em suas outras Missas. De fato, considerando-se as Missas de Perosi que foram publicadas ${ }^{7}$,

\footnotetext{
7 "Eis a lista completa das obras de Perosi que foram impressas no catálogo da Casa Ricordi (até 2005): La Passione di Cristo Secondo San Marco, La Risurrezione di Cristo, Missa Cerviana, Missa da Requiem a 3 voci machili, Missa 'Benedicamus Domino', Missa Eucharistica, Missa Pontificalis, Missa Secunda Pontificalis, Missa 'Te Deum laudamus'. E é isto. Dois oratórios e sete Missas. Menos que 4,5 horas de música. [...] Evidentemente que há outras editoras, sobretudo a Armelin (Pádua), que publicaram suas obras menores. Mas sendo a Casa Ricordi a soberana das casas editoriais da Itália, a brevidade da lista é ultrajante" (CIAMPA, 2006, p. 322; 353, tradução nossa).
} 
somente na Missa Prima Pontificalis (1897) encontra-se uma introdução de órgão que, com exceção do Kyrie, é repetida no início das demais unidades funcionais (Fig. 22).

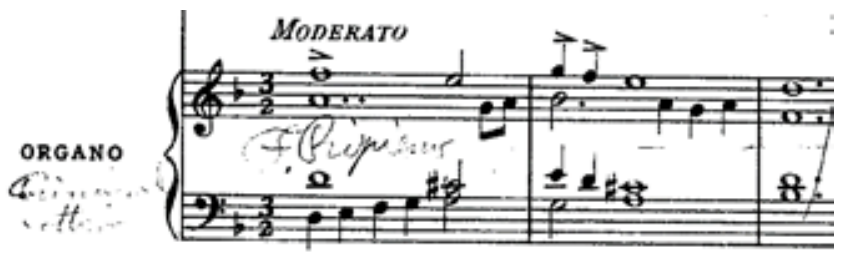

Fig. 22 - Perosi: tema de órgão recorrente na Missa Pontificalis (PEROSI, 1899).

Expandindo-se a análise para Missas de outros compositores do mesmo período que também compartilhavam dos ideais estéticos cecilianistas, facilmente se percebe que, ainda que seja bastante comum a escrita coral com simples acompanhamento de órgão, de modo algum é um procedimento padrão a utilização recorrente de um tema introdutório executado pelo órgão. Muitas vezes, as introduções instrumentais de tais Missas cecilianistas são breves frases de caráter convencional (definição da tonalidade, cadência preparatória à entrada do Coro), sem um caráter estritamente temático tal como o é a de Nepomuceno ${ }^{8}$.

\begin{tabular}{|c|c|c|c|c|}
\hline & \multicolumn{2}{|c|}{$\begin{array}{c}\text { NEPOMUCENO } \\
\text { Missa em Ré menor }\end{array}$} & \multicolumn{2}{|c|}{$\begin{array}{c}\text { PEROSI } \\
\text { Missa Te Deum laudamus }\end{array}$} \\
\hline \multirow{2}{*}{ KYRIE } & Introdução & c. $1-5$ & Introdução & c. $1-4$ \\
\hline & Interlúdio & c. $34-37$ & Interlúdio & c. $24-26$ \\
\hline \multirow{3}{*}{ GLORIA } & Introdução & c. $1-5$ & Introdução & c. $1-4$ \\
\hline & Interlúdio & c. $93-95$ & Interlúdio & $\begin{array}{l}\text { c. } 104-105 \\
\text { (transposto) }\end{array}$ \\
\hline & Final & $\begin{array}{l}\text { Amen } \\
\text { (Variação } \\
\text { temática) }\end{array}$ & Final & $\begin{array}{l}\text { Amen } \\
\text { (Variação } \\
\text { temática) }\end{array}$ \\
\hline \multirow{3}{*}{ CREDO } & Introdução & c. $1-5$ & Introdução & c. $1-4$ \\
\hline & \multirow{2}{*}{ Final } & \multirow{2}{*}{ Amen } & Interlúdio & c. $164-165$ \\
\hline & & & Final & Amen \\
\hline SANCTUS-BENEDICTUS & \multicolumn{2}{|c|}{$-\mathrm{I}$} & ntrodução & $\begin{array}{c}\text { c. } 1-4 \\
\text { (Escrita a } 4 \\
\text { vozes) }\end{array}$ \\
\hline \multirow{3}{*}{ AGNUS DEI } & Introdução & c. $1-4$ & Introdução & c. $1-2$ \\
\hline & Interlúdio & c. $33-35$ & Interlúdio & $\begin{array}{l}\text { c. } 18-20 \\
\text { (transposto) }\end{array}$ \\
\hline & Finalc & $.55-58 \mathrm{~F}$ & inal & c. $32-34$ \\
\hline
\end{tabular}

Tab. 1 - Recorrência do tema inicial ao longo da Missa (O Autor).

Finalmente, ainda em relação à possível proximidade estilística entre Nepomuceno

\footnotetext{
8 Ainda que todas as Missas de Perosi tenham acompanhamento para órgão, não se encontra nelas a recorrência de um elemento temático instrumental (Cf. Missas Davidica, Secunda Pontificalis, In honorem beati Amrosii, A 3 voci maschili, Eucharistica, S.S. Gervasii et Protasii, Benedicamus Domino e Patriarchalis). O Frei Pedro Sinzig OFM (1876-1952), alemão radicado no Brasil e bastante dedicado à causa da música sacra no Brasil, compôs várias Missas que, assim como a de Nepomuceno, também possuem uma escrita simples a duas vozes e acompanhamento de órgão (ou harmônio). Em nenhuma delas se encontra um elemento temático instrumental recorrente (Cf. Missas Brevis vide humilitatem Ex ore infantium, Exsultemus, Festiva, Jubilate e Rosa mistica).
} 
e Perosi, deve-se destacar que o compositor italiano utiliza em outra obra sua um tema melódico semelhante àquele utilizado por Nepomuceno como Introdução e elemento temático recorrente em sua Missa. Nos anos em que Perosi atuou em Milão, ele compôs uma série de composições para uma ou duas vozes que foram agrupadas em quatorze volumes intitulados Melodia Sacre, publicados entre 1897 e 1910. Os primeiros quatro volumes contêm somente motetos de Perosi, enquanto os subsequentes contêm alguns de sua autoria, e os últimos, nenhum ${ }^{9}$. No volume IV, de 1900, há um moteto a duas vozes (Soprano e Barítono) chamado Ecce panis angelorum, cujo início e fim apresentam um desenho melódico no órgão com subida ascendente por grau conjunto do Ré ao Si bemol e descida imediata ao Lá. Ao final, a descida melódica procede até o Fá, de forma semelhante ao perfil melódico empregado por Nepomuceno (até Mi). Além disso, destaque-se a mesma tonalidade (Ré menor) e o mesmo tipo de compasso (ternário simples) tanto em tal moteto de Perosi como na Missa de Nepomuceno (Fig. 23).
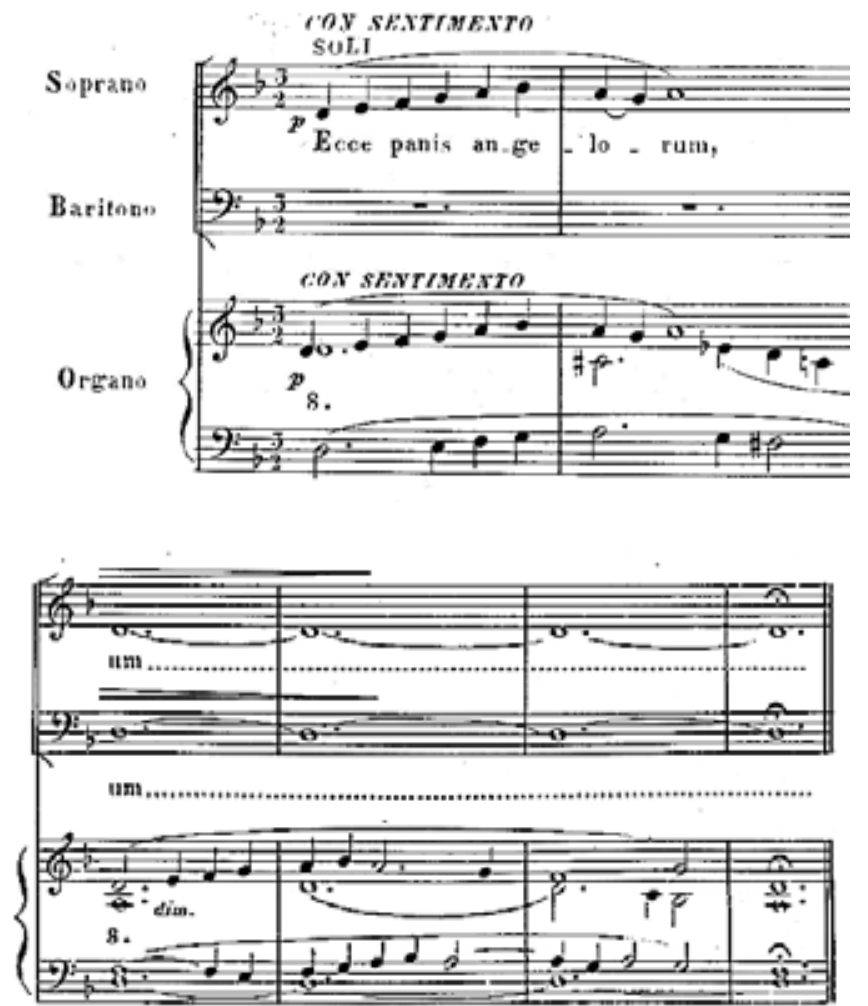

Fig. 23 - Perosi: tema do moteto Ecce panis angelorum (PEROSI, 1899).

Portanto, pode-se concluir:

1. Sob o aspecto da constituição intrínseca, o tema introdutório da Missa de Nepomuceno apresenta-se como uma estilização de uma figura melódica característica do Modo I no cantochão latino: Ré-Lá-Si bemol-Lá.

Diz o autor: "Se, por um lado, os grandes oratórios, aos ouvidos atuais, podem soar como pastiches datados de passagens interessantes mescladas a outras longas e desisteressantes, estes pequenos motetos em Latim - de uma a quatro vozes, com simples acompanhamento de órgão - por outro lado, são para mim a melhor prova do axioma de Santo Agostinho: 'Cantar é como rezar duas vezes'" (CIAMPA, 2006, p. 113114 , tradução nossa). 
2. Sob o aspecto do uso que Nepomuceno dá a tal tema introdutório, há uma recorrência em todos as unidades funcionais da Missa, com exceção do Sanctus-Benedictus, do que decorre que tal tema possui uma clara função unificadora ao longo da obra.

3. Sob o aspecto da localização do tema introdutório dentro de cada unidade funcional da Missa, há uma proximidade entre a obra de Nepomuceno e a Missa Te Deum laudamus de Perosi ${ }^{10}$.

\title{
3. O Kyrie
}

Imediatamente após a Introdução com solo de órgão tem-se, na Missa de $\mathrm{Ne}$ pomuceno, o canto do Kyrie eleison. O texto do Kyrie consiste em nove invocações: três vezes Kyrie eleison ("Senhor, tende misericórdia de nós"), três vezes Christe eleison ("Cristo, tende misericórdia de nós") e novamente três vezes Kyrie eleison ("Senhor, tende misericórdia de nós"). As três primeiras são dirigidas a Deus Pai; as três segundas a Deus Filho, e, as últimas, a Deus Espírito Santo, ${ }^{11}$ conforme explica Santo Tomás de Aquino (1225-1274), Doutor da Igreja:

\begin{abstract}
Este sacramento [da Eucaristia], compreendendo todo o mistério da nossa salvação, por isso é celebrado com mais solenidade que todos os outros. E porque lemos na Escritura - Vê onde põe o teu pé quando entras na casa de Deus; e: Prepara a tua alma antes da oração -, por isso, antes da celebração deste mistério, vem em primeiro lugar a preparação, para se bem fazer o que se segue. Dessa preparação a primeira parte é o louvar a Deus, que se faz no intróito, segundo àquilo da Escritura: Sacrifício de louvor me honrará; e ali o caminho por onde Ihe mostrarei a salvação de Deus. E esse louvor é tirado, no mais das vezes, dos salmos, ou pelo menos é cantado com um salmo; porque, como Dionísio diz, os salmos, como louvores, abrangem tudo o contido na Escritura. A segunda parte contém a comemoração da nossa miséria presente, quando o sacerdote implora misericórdia, dizendo Kyrie Eleison, três vezes pela pessoa do Pai; três pela pessoa do Filho, quando diz Christe Eleíson; e três pela pessoa do Espírito Santo, quando acrescenta Kyrie Eleíson. Três súplicas contra a nossa tríplice miséria - da ignorância, da culpa e da pena; ou para significar que as três pessoas estão reciprocamente uma na outra. (Suma teológica, III, q. 83, a. 4 , grifo nosso).
\end{abstract}

O Kyrie é, na verdade, o resto de uma ladainha de origem oriental adotada ao longo do século IV pela Liturgia romana e, por isso, inclusive, a razão de ser em língua grega, e não em latim. Inicialmente era uma espécie de rogação pública que os fiéis apresen-

\footnotetext{
10 Entendemos aqui que tal semelhança se dá sobretudo no âmbito da forma musical, e não no âmbito temático ou motívico. Pode-se entender que tal proximidade se dá por uma apropriação livre que Nepomuceno faz do modelo formal da Missa Te Deum laudamus de Perosi ou por um compartilhamento entre ambos os compositores de um esquema formal comum ao gênero musical em questão. Uma avaliação das demais partes da Missa de Nepomuceno, sobretudo do Sanctus, sugerem-nos que a primeira opção é mais provável.
}

11 Trata-se aqui da doutrina católica sobre a Santíssima Trindade: "Há um só Deus e não pode haver mais que um. Em Deus há três pessoas divinas, iguais e realmente distintas: o Pai, o Filho e o Espírito Santo" (Terceiro Catecismo da Doutrina Cristã, 1937, p. 20). 
tavam a Deus: o Diácono propunha aos fiéis alguma intenção (necessidades da Igreja, salvação dos povos, ordem das nações etc.) e estes respondiam Kyrie eleison. Com o tempo, abandonou-se as invocações, manteve-se o Kyrie eleison e, desde o século IX, limitou-se a nove essas invocações (REUS, 1944; BOULENGER, 1949, p. 233; 314)

Enquanto forma musical, pode-se considerar o Kyrie em três estilos musicais distintos: 1) no canto gregoriano, 2) na polifonia palestriniana e 3) na música moderna.

$\mathrm{Na}$ edição vaticana do Liber usualis encontram-se dezoito Ordinários gregorianos diferentes e mais alguns cantos ad libitum, resultando em um total de trinta Kyries ${ }^{12}$. Neste repertório há Kyries com melodias simples, sendo possivelmente bastante familiares aos fiéis na Antiguidade cristã: Kyrie XVIII, XI e XVI. Outros, por sua vez, possuem caráter melismático e certamente pertenciam aos solistas, os quais se alternavam com a Schola cantorum ${ }^{13}$. O aspecto geral das melodias é bastante variado, mas é comum que a última das nove invocações seja mais adornada que as demais, indicando-se, assim, que a série está sendo concluída (ASENSIO, 2016, p. 242-247). No que concerne ao esquema formal dos Kyries gregorianos, apresenta-se uma síntese na Tab. 2.

\begin{tabular}{|c|c|}
\hline Esquema AAA-BBB-AAA & Kyrie V \\
\hline Esquema AAA-BBB-AAA & Kyrie XVI \\
\hline Esquema AAA-BBB-CCC & Kyrie IX (ad lib.) \\
\hline Esquema AAA-BBB-CCC' & Kyries I-II-IV-VII-VIII-XI(A)-XII-XIII-XIV- \\
& XVII(A-B-C)-VII (ad lib.)-VIII (ad lib.) \\
\hline Esquema AAA-BBB-AAC & Kyries XI(B)-XVIII(A-B) \\
\hline & Kyries I(A-B)-III-III (ad lib.)-VI-IX-X-XV-IV (ad \\
\hline Esquema ABA-CBC-DED' & Kyrie I (ad lib.) \\
\hline Esquema ABA-BCB-DED' & Kyrie (ad lib.) \\
\hline
\end{tabular}

Tab. 2 - Esquemas formais nos Kyries gregorianos (ASENSIO, 2016, p. 245).

Em Palestrina, por sua vez, é comum que cada um dos três grupos do Kyrie constitua-se em um desenvolvimento temático próprio. Ocorre isto, por exemplo, na Missa Iste confessor a 4 vozes, baseada sobre um cantus firmus gregoriano, na qual a segunda frase do sujeito utilizado conduz ao Christe em um grau da escala distinta do usado no primeiro e no terceiro Kyrie. Às vezes, especialmente nas Missas a mais de quatro vozes, - Christe é executado por um contingente vocal menor que a primeira e que a terceira partes, tal como nas Missas Ad coenam Agni providi a 5 vozes, na Sine nomine a 6 vozes, na Aspice Domine a 5 vozes, na Salvum me fac a 5 vozes e na Beata Virgine a 6 vozes. Menos frequentemente ocorre a forma $A-B-A^{\prime}$, em que a terceira parte do conjunto (três últimas invocações do Kyrie) é uma repetição do começo, tal como na Missa Sine nomine a 4 vozes (BAS, 1947, p. 142-143).

\footnotetext{
12 Cf. Liber usualis, 1961, p. 16-86.

13 Entende-se Schola cantorum [Escola de cantores] como sinônimo de "coro", ou seja, um grupo de cantores que preparam e executam os cantos próprios de uma cerimônia litúrgica católica, seja cantando somente eles mesmos, seja liderando o canto de toda a congregação de fiéis. Por cantores ou solistas entende-se aqueles que, dentre os membros do coro, têm a função de executar sozinhos determinados trechos musicais, tais como a "entoação" do cantochão, isto é, a sua primeira frase, definindo-se, assim, a altura e o tempo a ser seguido pelos demais. As rubricas litúrgicas supõem que o número de cantores pode variar de um a quatro, dependendo da solenidade da ocasião (MILLS, 2008, p. 12).
} 
Na música moderna, pós-renascentista, finalmente, a tradicional divisão A-B-A ou A-B-C é mantida, mas a distinção das partes não se fundamenta simplesmente na caracterização temática, mas sim nas relações tonais:

O Kyrie, na forma considerada anteriormente, é quase sempre do tipo A-B-C, composto de três partes ou períodos distintos; entretanto, o sentido musical moderno tende particularmente à forma A-B-A', que apareceu já também nas melodias gregorianas e nas obras dos polifonistas; forma evidentemente sugerida pelo texto. Neste caso, o Christe requer um caráter algo distinto dos Kyrie primeiro e último, e tende para uma tonalidade distinta, e ainda alternando os Solos com o Coro, polifonia e homofonia etc. Por outro lado, a repetição do Kyrie ao final requer, por sua vez, certa amplificação, uma pequena coda. (BAS, 1944 , p. 148, tradução nossa).

No que concerne à forma musical do Kyrie, há ainda uma exigência encontrada na regulamentação da música sacra por parte da Igreja. Trata-se, basicamente, de que não se divida o Kyrie em peças independentes:

O Kyrie, o Glória, o Credo, etc., da Missa, devem conservar a unidade de composição própria do texto. Por conseguinte, não é lícito compô-las como peças separadas, de modo que, cada uma destas forme uma composição musical tão completa que possa separar-se das restantes e ser substituída por outra. (PIO X, 1903).

A partir de tais dados, analisaremos o Kyrie de Nepomuceno em si mesmo e em relação a estes quatro aspectos da música sacra: o gregoriano, a tradição polifônica, a música moderna (tonal) e a legislação eclesiástica.

De mogo geral, a Missa de Nepomuceno apresenta o esquema tradicional de alternância de texturas, homofônica e polifônica, assim como coral e solista, nas diferentes declamações dos textos litúrgicos. É através deste meio que o compositor confere certa variedade sonora dentro de um âmbito bastante limitado, como é o de duas vozes iguais. É pelas diferentes escritas musicais que, primordialmente, a Missa se subdivide em diferentes partes claramente identificáveis. Também é este um aspecto estilístico que insere a Missa de Nepomuceno diretamente no seio dos ideais estéticos cecilianistas, que explicitamente colocam a polifonia palestriniana, caracterizada pela alternância de texturas dentro da escrita coral, como protótipo idealizado para a música sacra moderna. Na Tab. 3 apresentamos a divisão formal do Kyrie de Nepomuceno quanto à textura musical: 


\begin{tabular}{|c|c|}
\hline \multicolumn{2}{|c|}{ Kyrie da Missa de Nepomuceno } \\
\hline Introdução & Solo de órgão \\
\hline Kyrie eleison & Homofônica - Uníssono \\
\hline Kyrie eleison & Contrapontística - Imitativa \\
\hline Kyrie eleison & $\begin{array}{c}\text { Contrapontística - Imitativa [Kyrie] } \\
\text { Homofônica [eleison] }\end{array}$ \\
\hline $\begin{array}{l}\text { Christe eleison } \\
\text { Christe eleison } \\
\text { Christe eleison }\end{array}$ & Voz 1 (solista) \\
\hline Interlúdio & Solo de órgão \\
\hline $\begin{array}{l}\text { Kyrie eleison } \\
\text { Kyrie eleison } \\
\text { Kyrie eleison }\end{array}$ & Contrapontística \\
\hline
\end{tabular}

Tab. 3 - Textura musical no Kyrie de Nepomuceno (O autor).

Em termos de extensão, tem-se a seção solista como uma seção menor (Tab. 4).

\begin{tabular}{|c|c|}
\hline Introdução & 4 compassos \\
\hline Kyrie eleison $(3 \mathrm{x})$ & 19 compassos \\
\hline Christe eleison $(3 \mathrm{x})$ & 10 compassos \\
\hline Interlúdio & 4 compassos \\
\hline Kyrie eleison $(3 \mathrm{x})$ & 13 compassos \\
\hline
\end{tabular}

Tab. 4 - Extensão das diferentes seções do Kyrie de Nepomuceno (O autor).

O tipo de Missa a duas vozes, ainda que constitua um âmbito sonoro muito mais limitado que aquele comumente utilizado pelos antigos mestres polifonistas (quatro, cinco, seis vozes), também permite vários tipos de uso de texturas musicais diferentes, como facilmente o demonstra a literatura musical cecilianista ${ }^{14}$.

A solução proposta por Nepomuceno em seu Kyrie, contudo, coincide mais uma vez com aquela de Perosi em sua Missa Te Deum laudamus. Ou seja, ambos conferem uma forma musical ao texto litúrgico do Kyrie valendo-se de uma divisão semelhante em termos de textura. Unindo-se este fato àquele já mencionado do uso recorrente do tema introdutório para órgão, tem-se mais um parâmetro musical que indica uma possível proximidade estilística entre as duas obras (Tab. 5).

\footnotetext{
14 A título de exemplo, nas Missas a duas vozes de Fr. Pedro Sinzig: 1) na Missa Vide humilitatem, os três primeiros Kyrie (para tutti do Coro) são em Homofonia; a seção do Christe (para duas vozes solistas) é dividida em duas partes, sendo a primeira em textura Imitativa e a segunda, Homofonia; os últimos três Kyrie (para tutti do Coro) são em Homofonia; 2) na Missa Exsultemus!, tem-se o primeiro Kyrie eleison em textura Imitativa e o segundo e terceiros, em Homofonia, sendo que os três são para tuttido Coro; a seção do Christe eleison (para duas vozes solistas) é inteiramente em textura Imitativa; os três últimos Kyrie eleison (para tutti do Coro) são quase inteiramente em textura Imitativa; 3) na Missa Jubilate, tem-se o primeiro Kyrie eleison (para tutti do Coro) inteiramente em Homofonia; a segunda seção (para duas vozes solsitas) em textura imitativa; a última seção (para tuttido Coro) é quase inteiramente em Homofonia, com exceção do último eleison, em textura Imitativa. De qualquer forma, nota-se que a seção central, do Christe eleison, sempre é reservada para vozes solistas. Nas Missas a duas vozes de Perosi, igualmente é recorrente a alternância de diferentes texturas entre as seções do Kyrie: 1) na Missa In honorem Beati Ambrosii, a primeira seção do Kyrie é em textura Contrapontistica e imitativa; a segunda seção é quase inteira com alternância das vozes, sem simultaneidade, com exceção do eleison final, que é em Homofonia; a terceira seção, enfim, intercala trechos sem imultaneidade das vozes com trechos em textura Contrapontística; 2) na Missa In honorem S.S. Gervasii et Protasii, as três seções assemelham-se na concatenação de trechos com textura Contrapontística, Homofônica e outros simplesmente com alternância não simultânea das vozes.
} 


\begin{tabular}{|c|c|c|}
\hline & $\begin{array}{c}\text { Nepomuceno } \\
\text { Kyrie da } \\
\text { Missa em Ré menor }\end{array}$ & $\begin{array}{c}\text { Perosi } \\
\text { Kyrie da } \\
\text { Missa "Te Deum laudamus" }\end{array}$ \\
\hline \multirow[t]{2}{*}{ Solo de órgão } & $\begin{array}{l}\text { Introdução caracterizada } \\
\text { como Tema }\end{array}$ & $\begin{array}{l}\text { Introdução caracterizada } \\
\text { como Tema }\end{array}$ \\
\hline & c. 1 a 3 & c. 1 a 4 \\
\hline \multirow{2}{*}{ Kyrie eleison } & Homofônica - Uníssono & Homofônica - Uníssono \\
\hline & c. 4 a 9 & c. 4 a 6 \\
\hline \multirow{4}{*}{ Kyrie eleison } & $\begin{array}{l}\text { Contrapontística - Imitativa } \\
\text { [Kyrie] }\end{array}$ & \multirow[t]{2}{*}{ Contrapontística - Imitativa } \\
\hline & c. 10 a 13 & \\
\hline & Homofônica [eleison] & \multirow{2}{*}{ c. 7 a 9} \\
\hline & c. 14 a 16 & \\
\hline \multirow{4}{*}{ Kyrie eleison } & $\begin{array}{l}\text { Contrapontística - Imitativa } \\
{[\text { Kyrie }]}\end{array}$ & Homofônica - Uníssono \\
\hline & c. 17 a 19 & \multirow{3}{*}{ c. 10 a 15} \\
\hline & Homofônica [eleison] & \\
\hline & c. 20 a 23 & \\
\hline \multirow{2}{*}{ Christe eleison } & Voz 1 (solista) & Voz 2 (solista) \\
\hline & c. 24 a 26 & c. 16 a 18 \\
\hline \multirow{2}{*}{ Christe eleison } & Voz 1 (solista) & Voz 2 (solista) \\
\hline & c. 26 a 29 & c. 19 a 21 \\
\hline \multirow{2}{*}{ Christe eleison } & Voz 1 (solista) & Voz 2 (solista) \\
\hline & c. 30 a 33 & c. 22 a 24 \\
\hline \multirow{2}{*}{ Solo de órgão } & Tema da Introdução & Tema da Introdução \\
\hline & c. 34 a 37 & c. 24 a 27 \\
\hline \multirow{2}{*}{ Kyrie eleison } & Contrapontística & Voz 1 \\
\hline & c. 39 a 42 & c. 27 a 29 \\
\hline \multirow{2}{*}{ Kyrie eleison } & \multirow{2}{*}{ Contrapontística } & Contrapontística \\
\hline & & c. 30 a 33 \\
\hline \multirow{2}{*}{ Kyrie eleison } & \multirow{2}{*}{ c. 43 a 50} & Contrapontística - Imitativo \\
\hline & & c. 34 a 39 \\
\hline
\end{tabular}

Tab. 5 - Comparativo Kyrie de Nepomuceno e de Perosi - textura musical (O autor).

Nota-se, assim, que há cinco semelhanças quanto à estrutura formal dos dois Kyries em termos de textura:

1. Introdução com solo de órgão caracterizada como tema recorrente na Missa;

2. Primeira seção (Kyrie eleison): início do canto com tutti do Coro em Uníssono seguido por trecho com textura Contrapontística e, em seguida, Homofônica ;

3. Segunda seção (Christe eleison): inteiramente com uma única voz solista (voz aguda em Nepomuceno e voz grave em Perosi);

4. $\quad$ Solo de órgão como Interlúdio, antes da Terceira seção;

5. Terceira seção (Kyrie eleison): textura predominantemente Contrapontística.

Sob o aspecto temático, além da dupla utilização (como introdução e como interlúdio) do tema inicial para solo de órgão, deve-se destacar o uso que Nepomuceno faz de uma típica figuração melódica gregoriana. Na primeira entrada do Coro, após a Introdução instrumental, tem-se o primeiro Kyrie eleison cantado pelas duas vozes em uníssono e em homofonia com o órgão, com indicação de dinâmica forte. Trata-se de 
uma linha melódica que, em seu contorno geral e em seu inciso ${ }^{15}$ final, muito se aproxima do estilo de cantochão (Fig. 24).

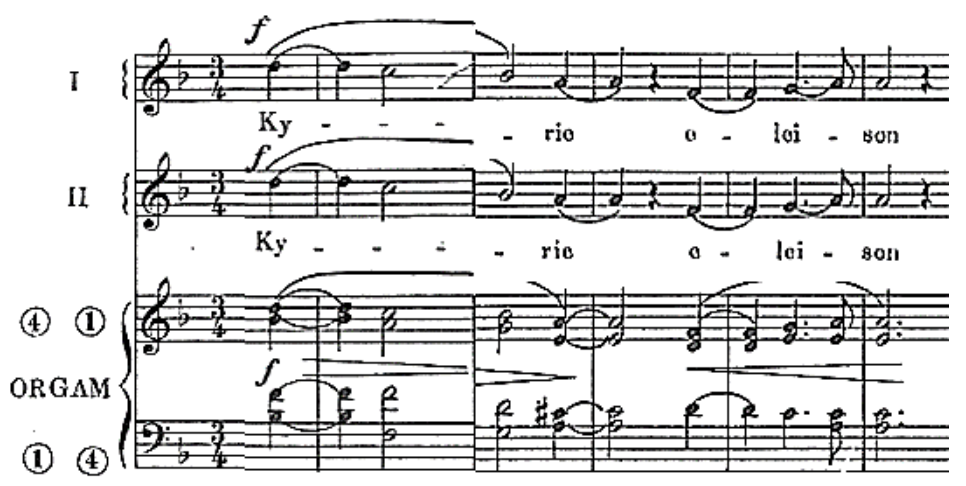

Fig. 24 - Nepomuceno: início do Kyrie (NEPOMUCENO, s.d.).

De fato, o inciso Fá-Sol-Lá-Lá com o texto eleison pode ser considerado uma citação literal de canto gregoriano que Nepomuceno insere em sua Missa (Fig. 25a). Em cinco Kyries gregorianos, encontra-se o mesmo inciso melódico com o texto eleison no final de alguma das frases musicais. Nos Kyries II (ad lib.) e X há as mesmas notas (Fá-Sol-Lá-Lá) (Fig. 25b, 25c); nos Kyries XV, XVI e XVIII há o mesmo desenho melódico, mas com as notas Sol-Lá-Si (Fig. 25d, 25e. 25f); enquanto que no Kyrie $V$ utiliza-se as notas Mi-Fá-Sol, ou seja, com um semitom inicial (Fig. $25 \mathrm{~g}$ ).

a:

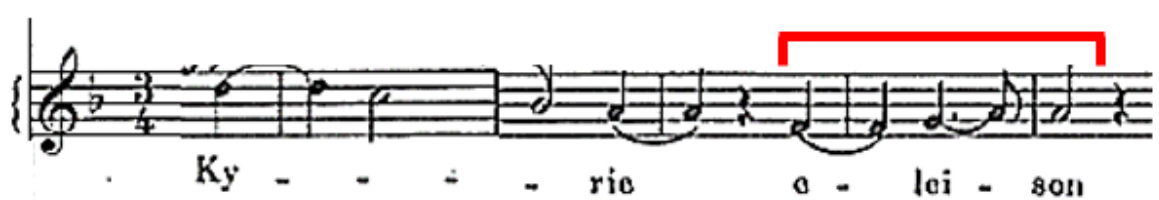

b:
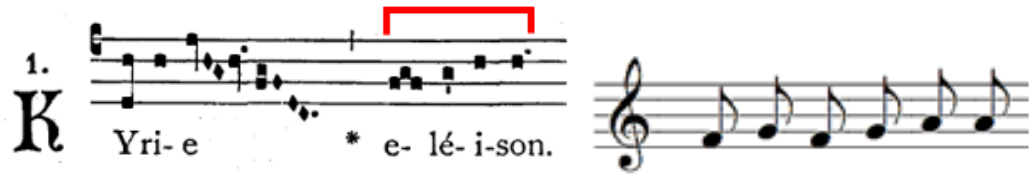

c:

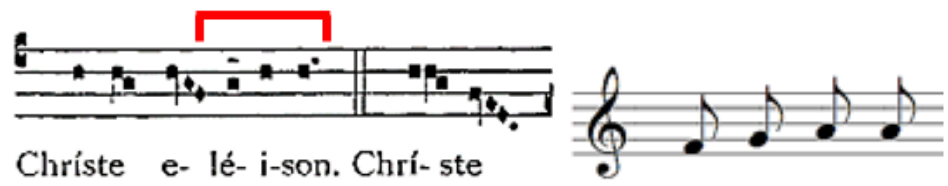

$\mathrm{d}:$

15 Ainda que atualmente esteja em desuso, utilizamos a nomenclatura que Ferretti emprega para análise formal de cantos gregorianos (Cf. 1934, p. 48-63). Trata-se, na verdade, dos princípios expostos por Giulio Bas em seu tratado de forma musical, os quais Ferretti aplica ao cantochão (Cf. p. 43). 


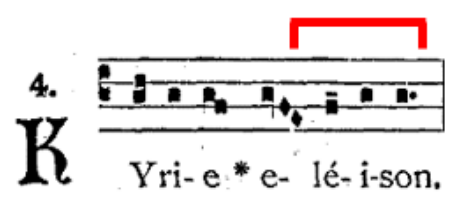

e:

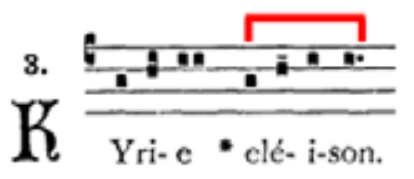

f:

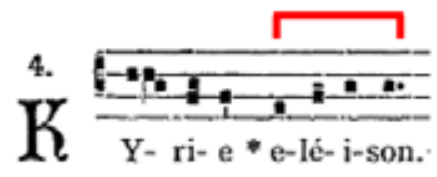

g:

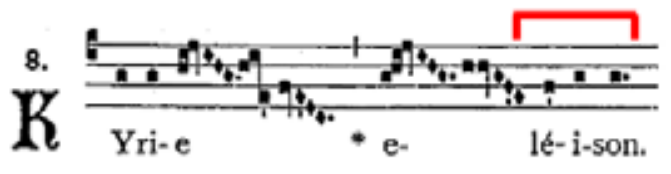

Fig. 25 - Inciso melódico característico no Kyrie de Nepomuceno e nos Kyries gregorianos II (ad lib.), X, XV, XVI, XVIII e V (NEPOMUCENO, s.d.; Liber Usualis, 1961, p. 28, 43, 56, 59, 62 e 80).

Trata-se certamente de um pequeno motivo melódico de grande antiguidade na Liturgia romana e, haja vista a sua recorrência dentro do tradicional repertório do cantochão, representa uma configuração musical que facilmente remete ao canto litúrgico:

\begin{abstract}
O motivo melódico final de A [Kyrie XVIII] é idêntico ao desenho A do Kyrie XVI. Este tema melódico forma parte fundamental de outras muitas melodias, inclusive acrescentando-se o adorno de semitom acima, e em uma escrita diferente (Fá-Sol-Lá-Si bemol-Lá) como ocorre no XVIII (B) de defuntos ou com a subida dissimulada do Si ao Dó que podemos ver no Kyrie I (Sol-Lá-Dó). Como destacou acertadamente Daniel Saulnier este tema (Dó-Ré-Mi ou seus correspondentes transpostos a Fá ou Sol) era o tema primitivo do canto da litania romana. (ASENSIO, 2016, p. 244-245, tradução e grifos nossos).
\end{abstract}

Considerando-se, contudo, a linha melódica completa do primeiro Kyrie eleison de Nepomuceno, há uma proximidade com a melodia final da seção central das três invocações Christe eleison do Kyrie I gregoriano. Trata-se de uma descida melódica por grau conjunto no âmbito de uma $4^{\underline{a}}$ justa seguida por um salto de $3^{\underline{a}}$ e, finalmente, este salto é preenchido com grau conjuntos de forma ascendente (Fig. 26). 


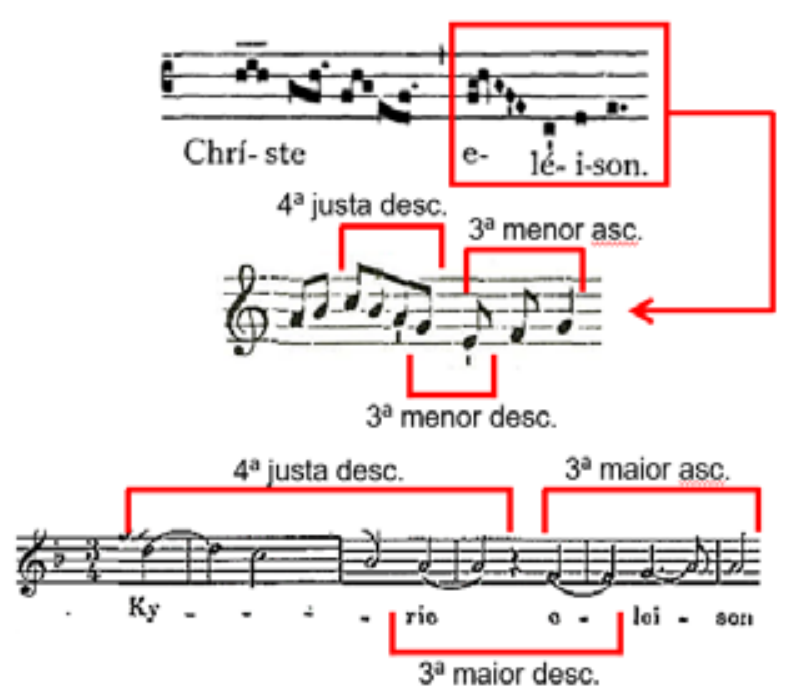

Fig. 26 - Semelhança de perfil melódico entre o Kyrie de Nepomuceno e o Kyrie / gregoriano (NEPOMUCENO, s.d.; Liber Usualis, 1961, p. 16).

Procedimento semelhante a este, a saber, o de inserir uma citação de melodia gregoriana no início do Kyrie pode ser encontrada também na Missa Choralis de Liszt, obra esta também marcada pela influência cecilianista. Esta obra Liszt a inicia com a melodia da antífona gregoriana Sacerdos in aeternum (Fig. 27).

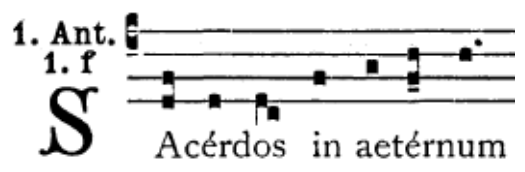

Alt.

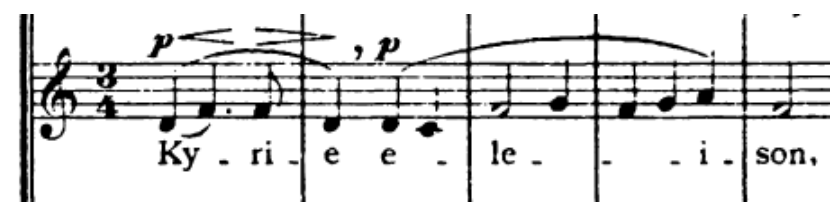

Fig. 27 - Liszt: início do Kyrie da Missa Choralis (LISZT, 1918; Liber Usualis, 1961, p. 956).

Ao final da primeira seção do Kyrie de Nepomuceno, na terceira invocação Kyrie eleison, tem-se novamente um desenho melódico conclusivo que também remete ao cantochão tradicional. A Voz 1 executa uma descida melódica por grau conjunto dentro do âmbito de uma 6a menor, de Dó até Mi, enquanto a Voz 2 faz um movimento descendente idêntico, transposto uma 5a justa abaixo, de Fá a Lá. Ainda que o eleison seja em uma textura homofônica, o Kyrie inicia-se com uma defasagem rítmica entre as vozes, o que, aliado à distância de uma 5a justa entre ambas as linhas melódicas, caracteriza uma breve passagem em textura imitativa. Considerando-se as relações intervalares da linha melódica da Voz 2 neste trecho, tem-se: Semitom-Tom-Tom-Tom-Semitom, dentro do âmbito de uma 6 menor descendente. É praticamente o mesmo contorno melódico do último Kyrie eleison do Kyrie XVI gregoriano, no qual em eleison há a nota mais aguda da linha, um Dó, e, logo em seguida, há uma descida melódica por grau conjunto no âmbito de uma 6a menor (de Dó a Mi, configurando também as relações Semitom-Tom-Tom-Tom-Semitom) (Fig. 28). 

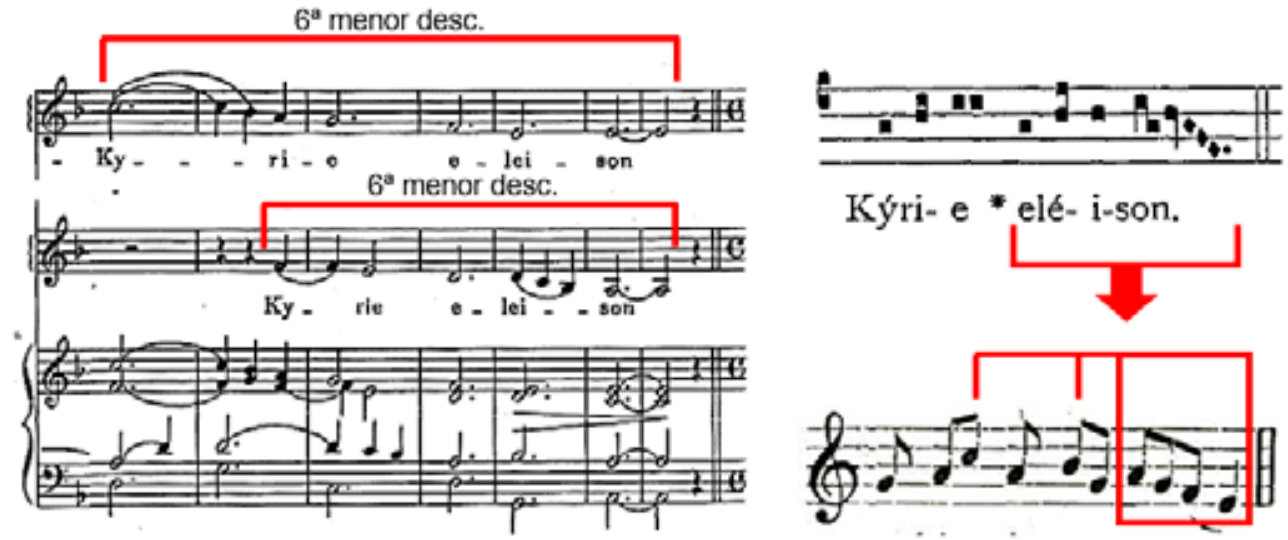

Fig. 28 - Semeınança de pertı meıodıco entre o kyrıe de Ivepomuceno e o kyrıe xvı gregorıano IIVtPUIvIULtIVU, s.d.; Liber Usualis, 1961, p. 59).

Na seção central, Christe eleison, para Voz 1 solista, tem-se uma variação temática sobre a primeira frase cantada pelo Coro em uníssono no início do Kyrie: descida melódica a partir da nota mais aguda da frase, seguida por cadência ascendente em eleison. Nas três invocações Christe eleison é este padrão que se repete, variando-se apenas, em termos melódicos, a utilização ou não de saltos ou bordaduras. As terminações das três frases remetem também a algumas conclusões melódicas típicas do Kyriale gregoriano (Tab. 6).

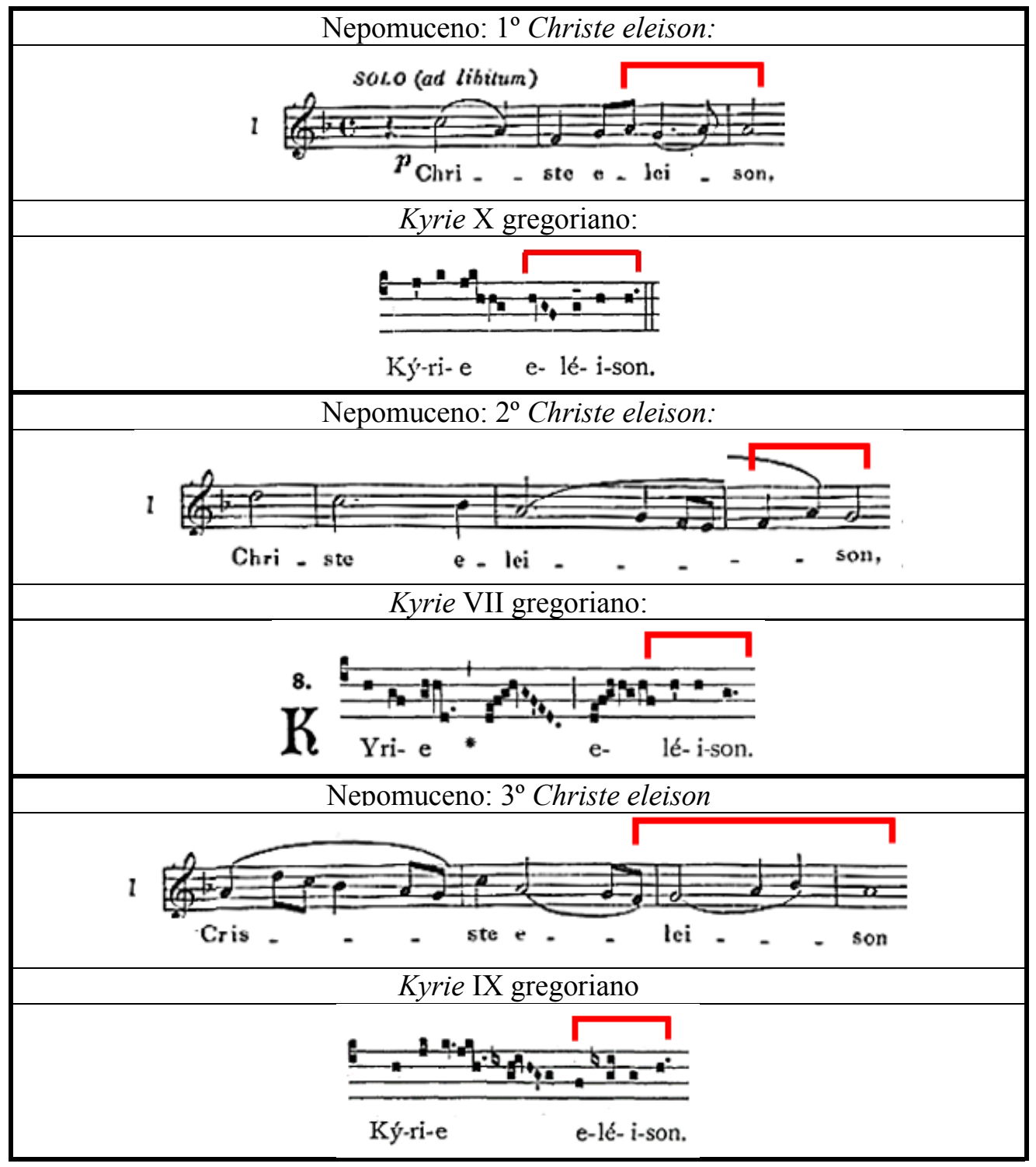


Tab. 6 - Seção do Christe eleison de Nepomuceno e Kyries gregorianos (NEPOMUCENO, s.d.; Liber usualis, 1961, p. 34, 40 e 43).

A terceira parte do Kyrie de Nepomuceno, com as três últimas invocações do Kyrie eleison, inicia-se no compasso 34 com a repetição do tema inicial para órgão solo. Em seguida, retorna o tutti do Coro após o solo da seção anterior. A Voz 1 declama duas vezes Kyrie eleison, enquanto a Voz 2, três vezes. Musicalmente, trata-se de um trecho claramente contrastante em relação tanto à primeira parte (Kyrie eleison) como à segunda (Christe eleison). A primeira parte do Kyrie (compassos 1 a 23) constitui-se por uma notória distinção entre os três primeiros Kyrie eleison: 1) uníssono com estilização gregoriana, 2) imitação e 3) imitação com estilização gregoriana. A segunda parte (compassos 24 a 33) caracteriza-se pela voz solista que emprega contornos melódicos e terminações muito próximas do estilo gregoriano. A terceira (compassos 34 a 50), por sua vez, caracteriza-se por uma textura coral contrapontística, com movimentos melódicos predominantemente contrários entre as duas vozes e defasagem entre as entradas do texto, gerando uma superfície sonora mais próxima à polifonia sacra tradicional. $O$ único ponto em que as vozes se encontram no que concerne ao ritmo e à declamação do mesmo texto é justamente no último compasso, na finalização do Kyrie.

Se, por um lado, algumas figurações melódicas das duas seções anteriores do Kyrie remetiam ao estilo do cantochão, há, na terceira seção, um tratamento de dissonâncias que aproxima a obra de Nepomuceno a determinadas características estilísticas da tradicional polifonia palestriniana. Trata-se do duplo uso da suspensão entre os compassos 45-46 e entre os compassos 47-48 (Fig. 29, 30 e 31). No penúltimo compasso, há uma dissonância no primeiro tempo sem a preparação no compasso anterior. A harmonização que Nepomuceno coloca no órgão, entretanto, indica também uma utilização do efeito de suspensão. O mesmo efeito na parte instrumental é utilizado em mais cinco momentos do Kyrie: três vezes na primeira seção (duas vezes no segundo Kyrie eleison [compassos 10-11 e 12-13]) e duas vezes na terceira seção (compassos 45-46 e 47-48). A escrita para órgão que Nepomuceno utiliza neste Kyrie é, em geral, na tradicional forma a quatro vozes e, via de regra, apresenta a voz superior como um dobramento da linha vocal. Em algumas passagens, sobretudo na segunda seção, Christe eleison, a parte do órgão apresenta alguns elementos melódicos e harmônicos próprios da escrita contrapontística, como, por exemplo, a suspensão com bordadura no compasso 27 e as notas passagens no compasso 28.

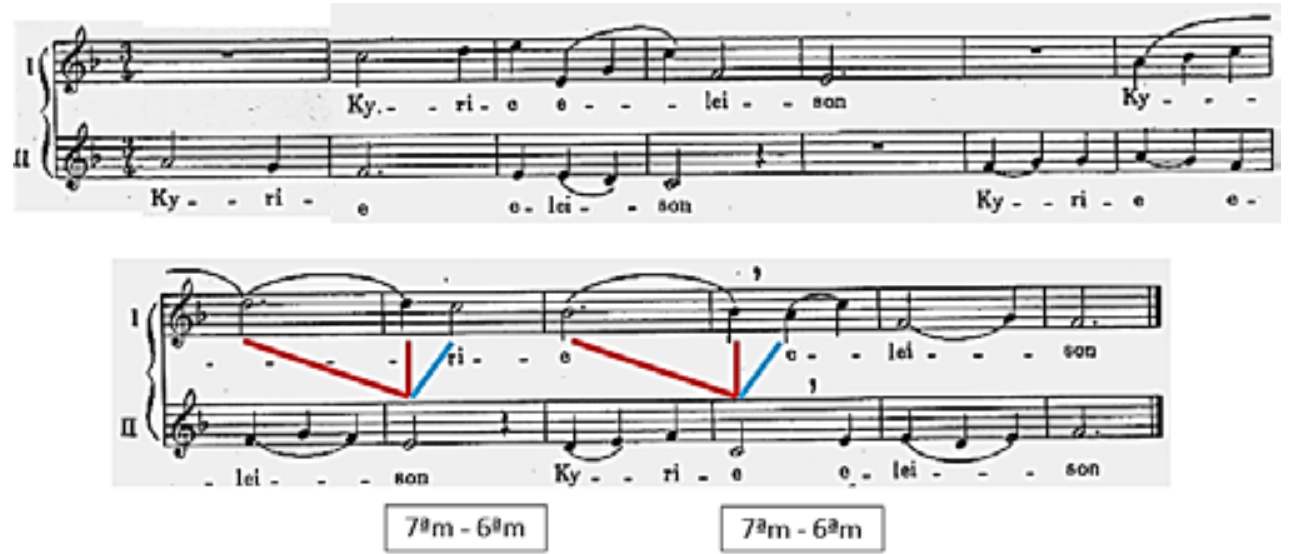

Fig. 29 - Nepomuceno: tratamento da dissonância na linha vocal da $3^{\text {a }}$ parte do Kyrie (NEPOMUCENO, s.d.). 


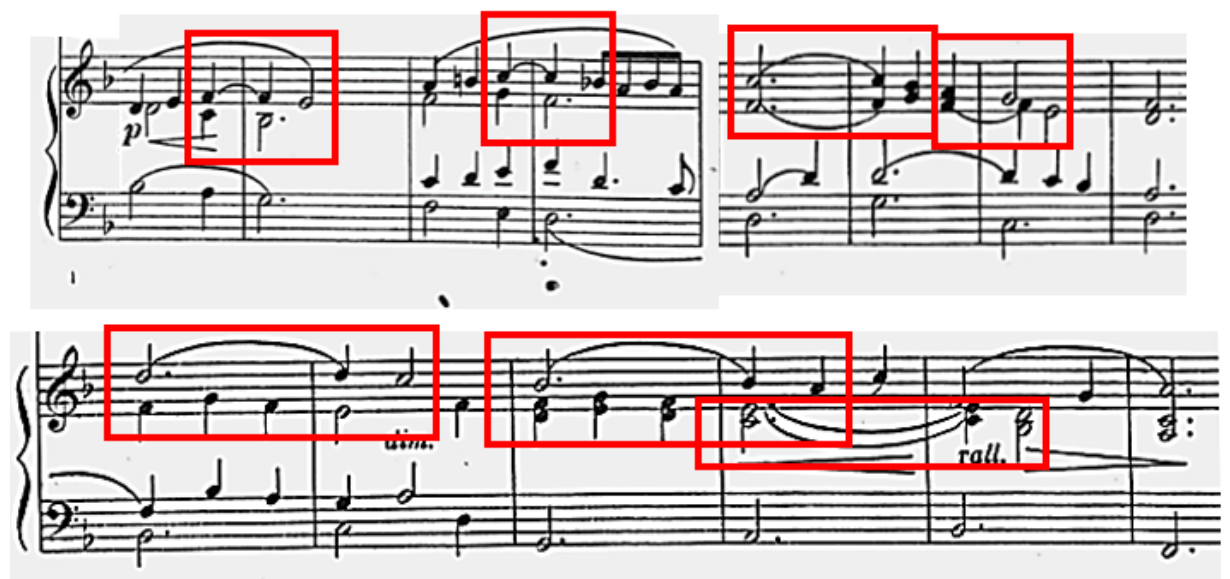

Fig. 30 - Nepomuceno: tratamento da dissonância na parte instrumental da $3^{a}$ parte do Kyrie (NEPOMUCENO, s.d.).

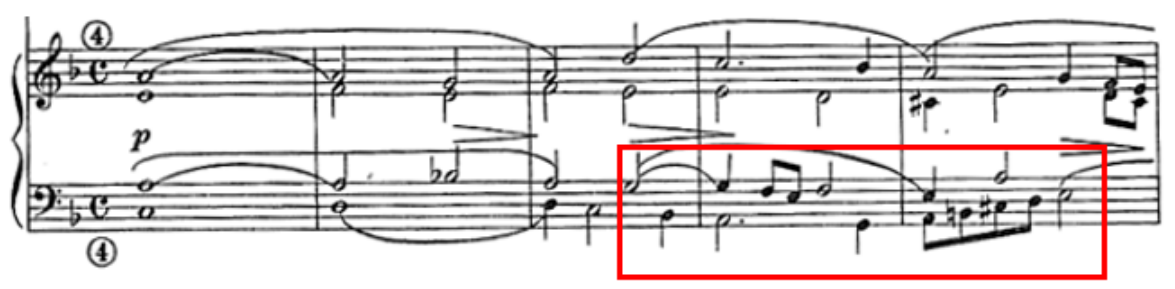

Fig. 31 - Nepomuceno: escrita contrapontística para órgão na $2^{a}$ parte do Kyrie (NEPOMUCENO, s.d.).

Quanto ao tipo de harmonização empregada, a primeira invocação Kyrie eleison, contudo, exige uma consideração à parte. De fato, é o único momento em que as duas vozes estão em perfeito uníssono e em que o órgão as acompanha dobrando a linha melódica em ritmo estritamente idêntico ao coro. Neste ponto, Nepomuceno utiliza somente tríades em estado fundamental. Unindo-se este fato àquele já mencionado de que esta primeira frase remete diretamente ao estilo de cantochão, parece-nos plausível supor que o compositor aqui se utilize pontualmente de uma das técnicas bastante em voga no final do século XIX e princípios do século XX para acompanhamento ao órgão do canto gregoriano: a cada nota do cantochão corresponde no órgão um acorde com notas pertencentes ao modo da peça gregoriana e preferencialmente em estado fundamental. É, em suma, o procedimento proposto no Traité théorique et pratique de l'accompagnement du plain-chant de Louis Niedermeyer e Joseph d'Ortigue, publicado em 1856.

O referido tratado apresenta algumas regras básicas para o acompanhamento ao órgão do canto gregoriano: (NIEDERMEYER; D'ORTIGUE, 1905, p. 14-16)

1. Usar exclusivamente em cada modo as notas da escala.

2. Usar frequentemente as tríades da nota final e da dominante de cada modo.

3. Usar exclusivamente as fórmulas harmônicas próprias às cadências de cada modo.

4. Não usar no acompanhamento do cantochão outro acorde senão as tríades consonantes e sua primeira inversão.

5. As leis que governam a melodia gregoriana (p.ex.: uso do Si bemol) devem ser observadas também em cada uma das (quatro) vozes do acompanhamento instrumental. 
6. Sendo a melodia o mais essencial do cantochão, ela deve sempre estar na voz superior do acompanhamento instrumental.

Sabe-se que Liszt, por exemplo, tinha em bom apreço o Traité e, inclusive, constam, na edição que ele possuía, algumas anotações suas ao lado das regras de Niedermeyer $^{16}$. E, de fato, este tipo de harmonização do cantochão se tornou corrente e, nas obras religiosas de Liszt, por exemplo, figura fortemente ${ }^{17}$. A título de exemplo, pode-se citar o seu Te Deum II, datado de 1853, que não é outra coisa senão uma simples harmonização de um Te Deum gregoriano na qual se verifica a técnica de inserir um acorde do modo sob cada nota da melodia gregoriana (Fig. 32).

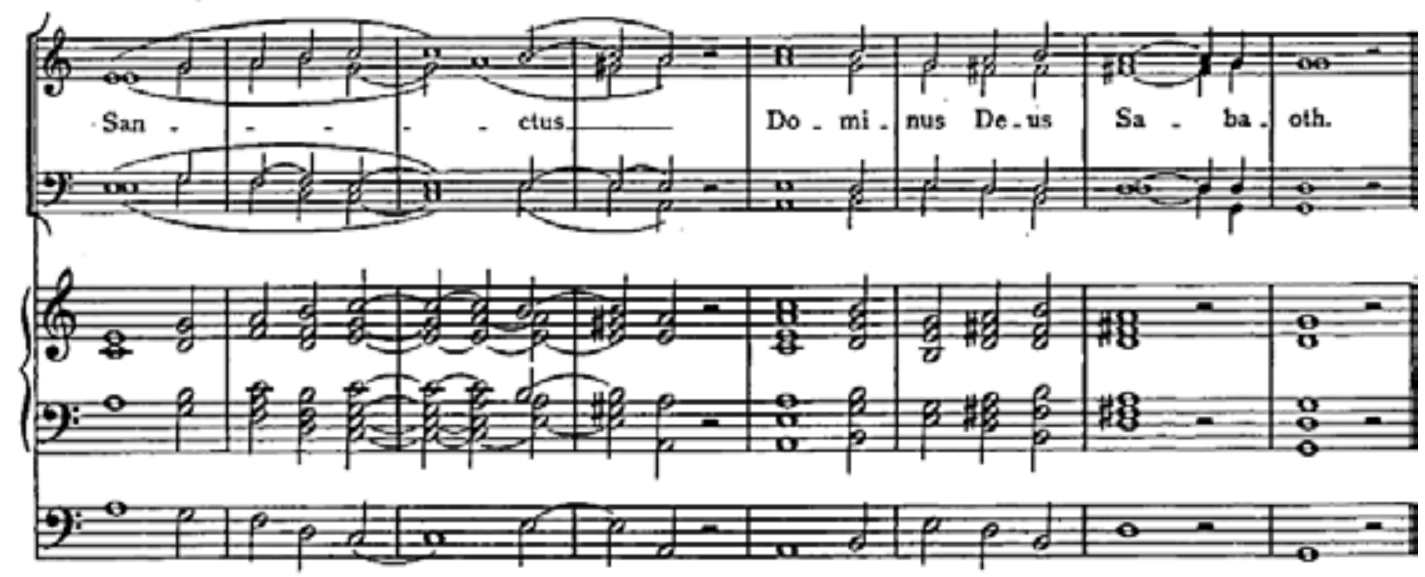

Fig. 32 - Liszt: exemplo de harmonização do cantochão em Te Deum I/ (LISZT, 1936).

Pode-se encontrar este tipo de harmonização do gregoriano também em Perosi. $\mathrm{Na}$ Missa De beata, que, além de algumas peças originais para órgão, consiste basicamente em uma versão harmonizada de uma Missa completa (Ordinário extraído da Missa IX gregoriana e o Próprio da Missa do Dia de Natal), encontra-se a mesma concepção para a harmonização do cantochão: acordes consonantes, um para cada nota da melodia (Fig. 33). Não há dissonâncias.

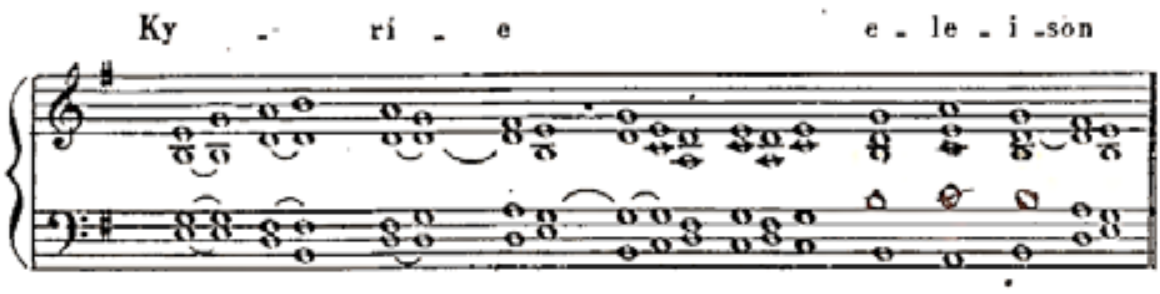

Fig. 33 - Perosi: exemplo de harmonização do cantochão na Missa De beata (PEROSI, s. d.).

\footnotetext{
16 "Outro livro trazendo sinais de uso por Liszt é o Traité théorique et pratique de l'accompagnement du plain-chant de Louis Niedermeyer e Joseph d'Ortigue publicado em 1859. D'Ortigue conhecia Liszt desde sua juventude em Paris. Liszt escreveu de Weimar a ele em 1850: 'A obra que você menciona concernente à liturgia tomará parte certamente entre as coisas mais conscienciosas e valorosas, e agrada-me ainda mais saber sobre isto, pois se trata de um assunto caro ao meu coração. Você não pensa que poderia incluir alguns textos musicados que poderiam ser escolhidos entre os mais amáveis cantos católicos?'" (MERRICK, 2008, p. 91-92, tradução nossa).
} 17 "Quando é dado tratamento de tutti do Coro e da Orquestra, como em algumas partes do [Oratório] Christus, por exemplo, o efeito pode
ser impressionante" (MERRICK, 2008, p. 92, tradução nossa). 
É exatamente este procedimento que Nepomuceno parece fazer uso no início de sua Missa, na primeira invocação do Kyrie eleison. Que ele estivesse familiarizado com tal tipo de acompanhamento do cantochão claramente o demonstra a sua própria harmonização do hino gregoriano Hodie Christus natus est em sua obra para piano chamada Cloches de Noel (Fig. 34). Com efeito, nesta peça pode-se notar o predomínio de tríades em estado fundamental ou em primeira inversão sobre as notas finalis (i grau - Ré) e dominante ( $v$ grau - Lá), tal como preconizado por Niedermeyer em suas primeiras duas regras para acompanhamento do gregoriano. É provável que Nepomuceno tenha aproximado-se de tais concepções teóricas acerca do acompanhamento do gregoriano durante seus estudos em Paris, na Schola Cantorum.
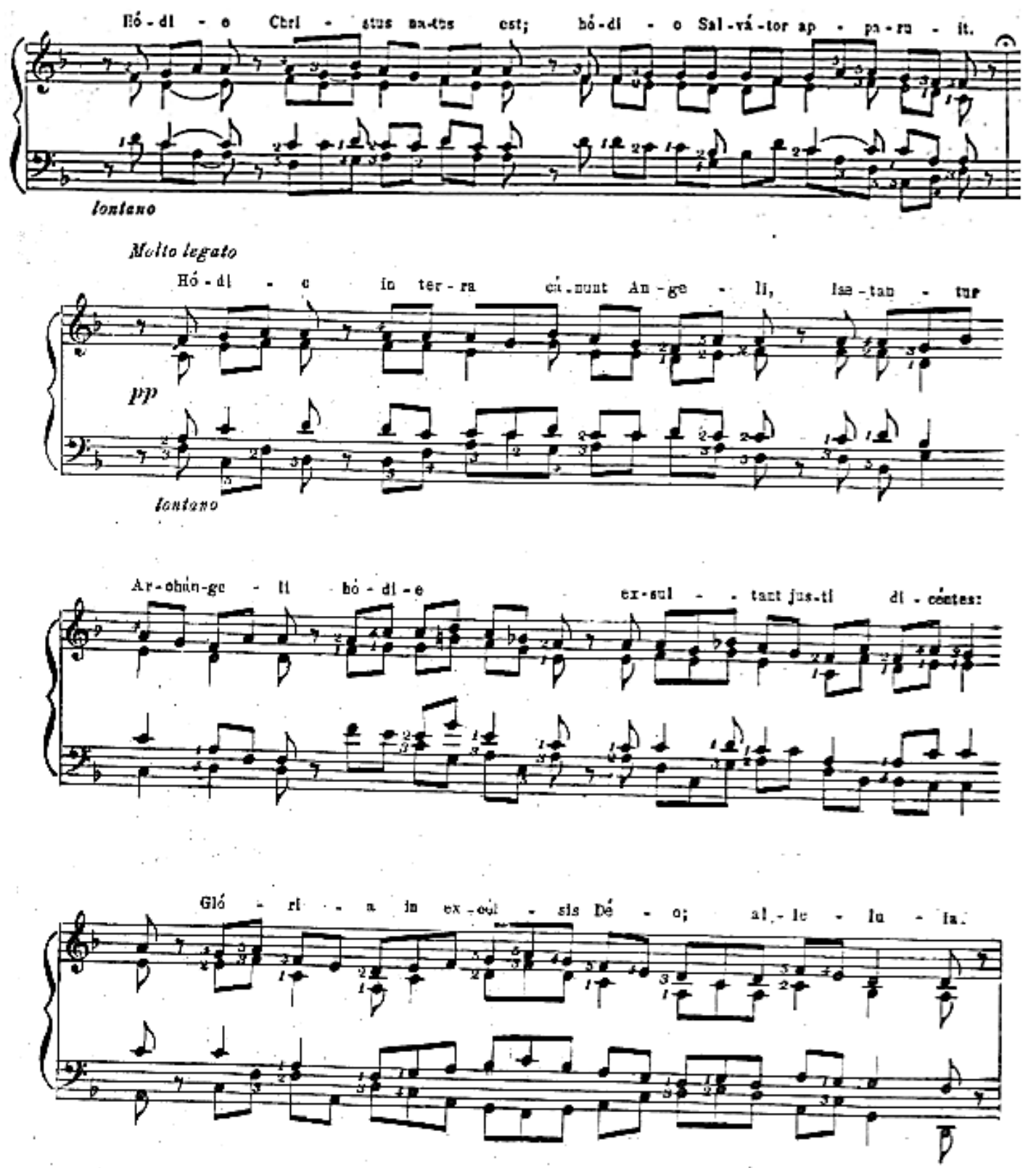

Fig. 34 - Nepomuceno: cantochão harmonizado em Cloches de Noël(NEPOMUCENO, s.d.). 
Destarte esta peculiaridade da escrita para órgão nos primeiros compassos do Kyrie, é na parte instrumental que primordialmente cabe a função de definição inequívoca da estrutura harmônica. Com efeito, diferentemente da tradicional escrita a quatro vozes, a textura a duas vozes não permite, a priori, uma clara configuração de acordes e, portanto, exige do acompanhamento instrumental um adequado suporte sonoro para a formação dos encadeamentos harmônicos.

Ao longo dele só há acordes diatônicos, considerando-se a tonalidade de Ré menor. Digno de nota, contudo, é o fato de o Kyrie se encerrar em Fá maior, ou seja, na relativa maior da tonalidade. Na verdade, Nepomuceno parece valer-se das diferentes possibilidades de acordes permitidas pelo uso do modo menor ( $v$ grau maior e menor, alterações do sexto e do sétimo grau etc.) para conferir um certo colorido modal à sua Missa como um todo. Por um lado há a presença do Dó\#, sensível de Ré menor, em alguns acordes da parte do órgão, indicando a clara conotação tonal da obra, ainda que na linha vocal não haja um Dó\# sequer (todos os Dó's são naturais). Por outro lado, há o uso constante do $v$ grau menor, principalmente nos finais de frase da primeira seção (compassos 9, 16 e 22), e não se utiliza a cadência V-I nos finais de seção, dando-se preferência às relações IV-I (compassos 21-22, 32-33 e 49-50) (Fig. 35 e 36).
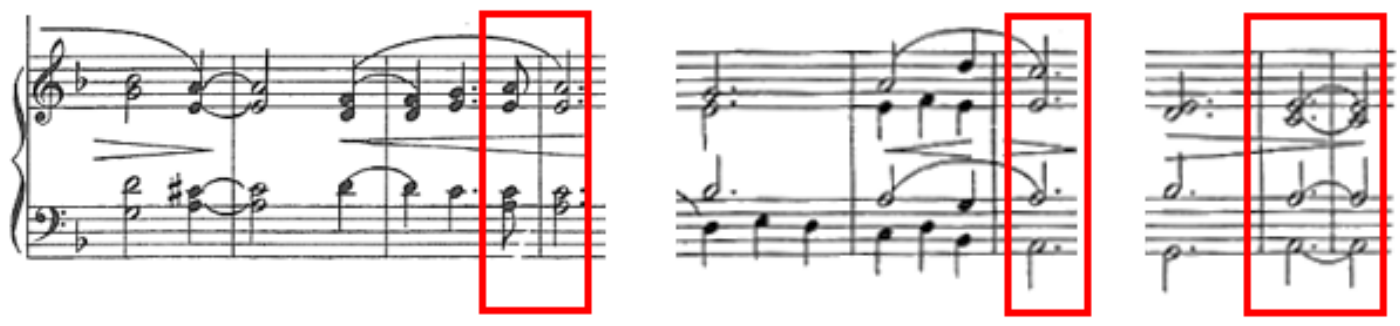

Fig. 35 - Nepomuceno: uso da v grau menor no Kyrie (compassos 9, 16 e 22) (NEPOMUCENO, s.d.).

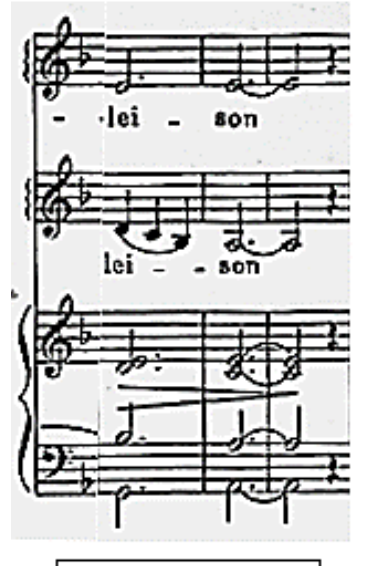

Ré $\mathrm{m}: \mathrm{ii}_{6}{ }_{6 / 5-\mathrm{V}}$
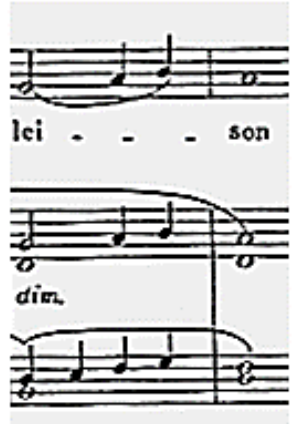

Ré m: iv6-i
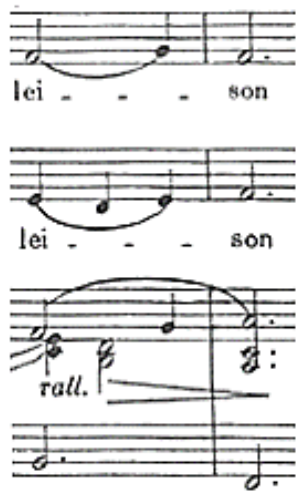

Fá M: IV-I

Fig. 36 - Nepomuceno: uso da relação IV-I nos finais de seção do Kyrie (NEPOMUCENO, s.d.).

No que concerne à estrutura harmônica do Kyrie de Nepomuceno, nas Fig. 37 e 38 apresentamos uma síntese, podendo-se verificar a cooperação também da harmonia para a clara divisão tripartite. 


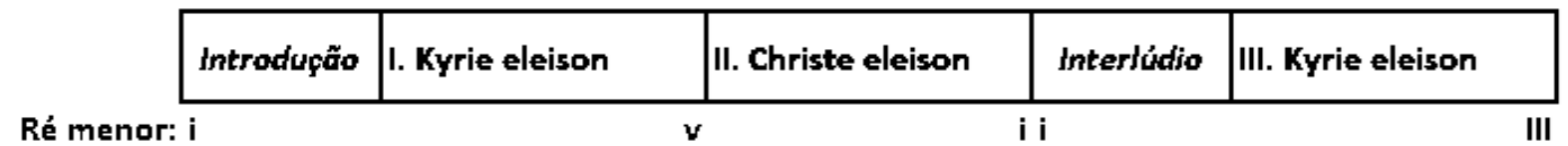

H.g. 3 / - Nepomuceno: estrutura harmonıca do Kyrie (U autor).

Primeira seção - Kyrie eleison (compassos 5 a 23):
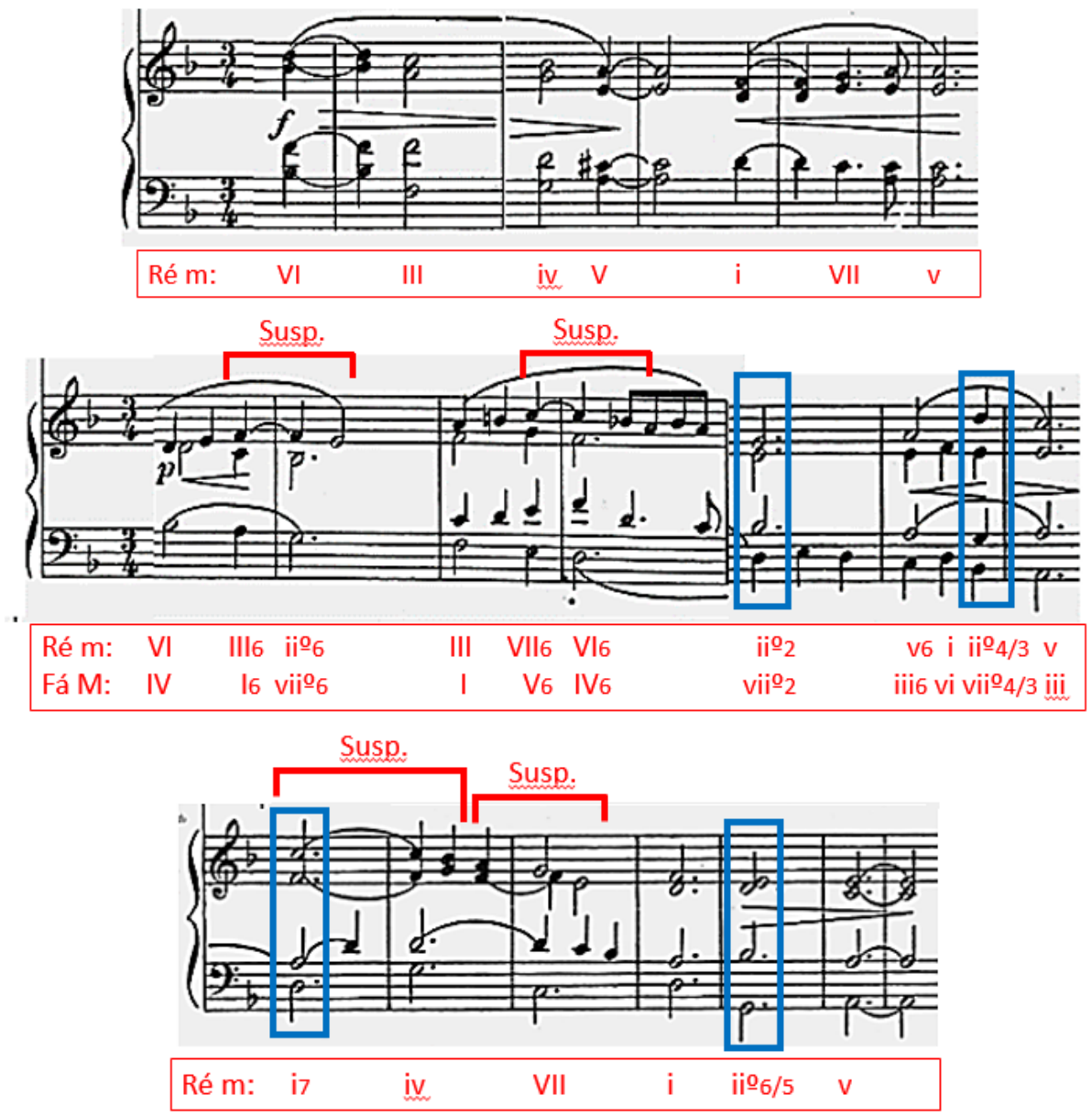

Segunda seção - Christe eleison (compassos 24 a 33):

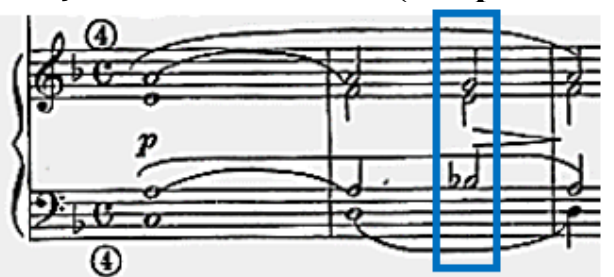

(4)

\begin{tabular}{lllll}
\hline Ré m: v6 & i & ii2 & i
\end{tabular}

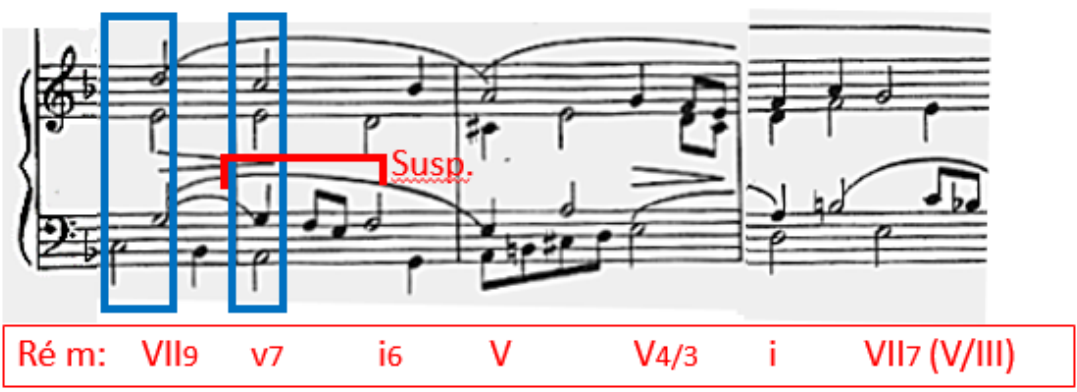




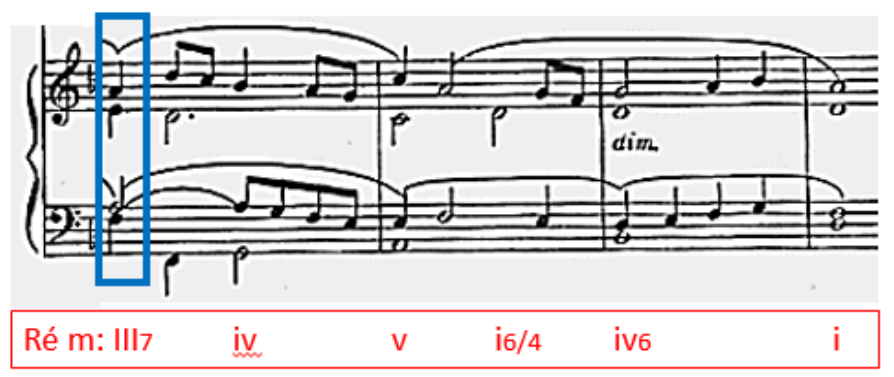

Terceira seção - Kyrie eleison (compassos 38 a 50):
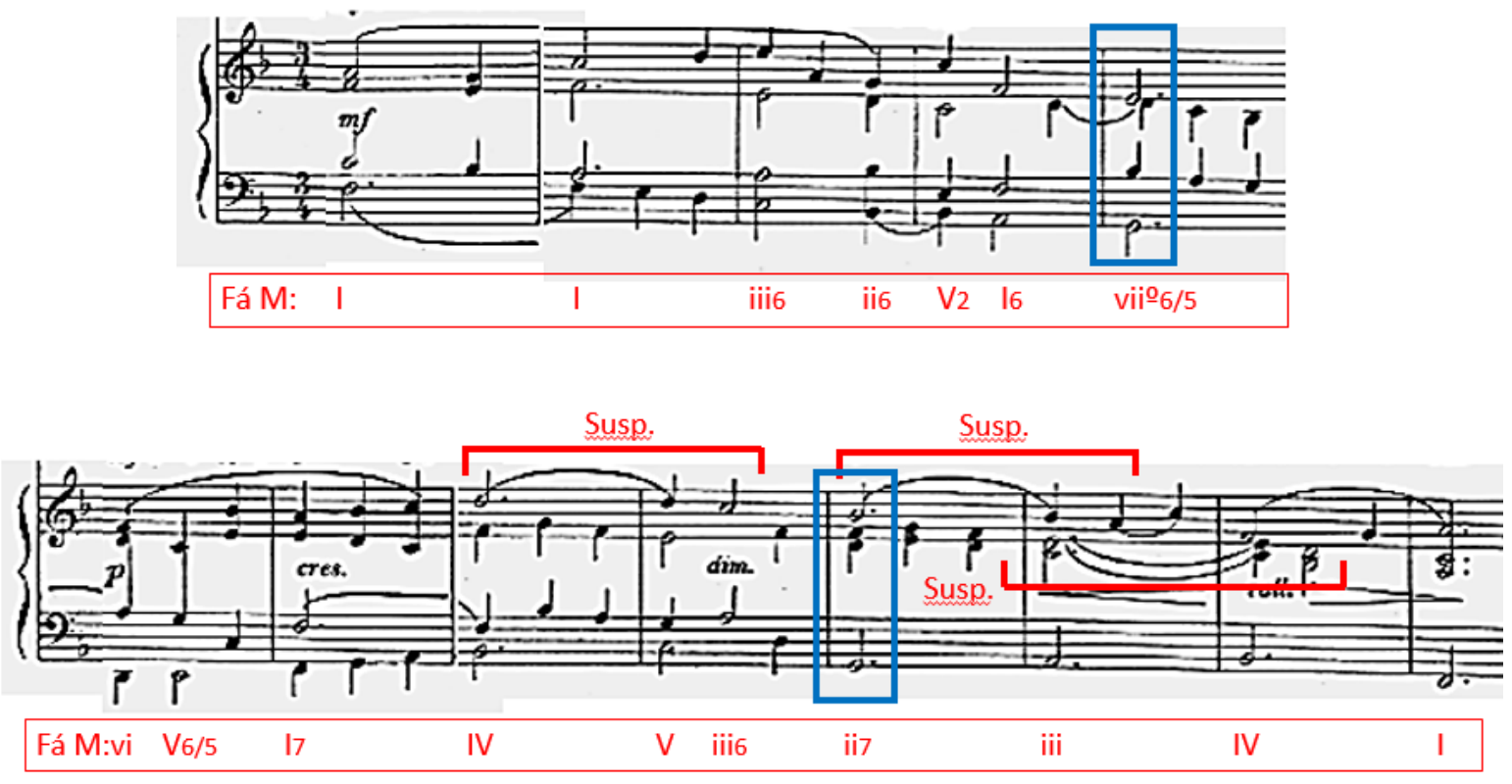

Fig. 38 - Nepomuceno: análise harmônica da parte instrumental (O autor).

Além da concatenação de diferentes texturas (uníssono, imitação, homofonia, Coro/Solista etc.) e da estrutura harmônica (tônica - v grau menor - tônica - relativa maior), há alguns outros parâmetros que também cooperam à organização do Kyrie.

Do ponto de vista rítmico, a Introdução e a primeira seção (Kyrie eleison - compassos 1 a 23) estão em compasso ternário simples, com a indicação de andamento Andante Maestoso. A segunda seção (Christe eleison - compassos 24 a 33) apresenta uma alteração para quaternário simples e a indicação Più lento. O Interlúdio e a terceira seção retornam ao compasso ternário simples e ao tempo inicial. Esta distinção das fórmulas de compasso e dos andamentos ao longo das diferentes seções do Kyrie pode ser considerada um procedimento padrão nas Missas cecilianistas. ${ }^{18}$ Esta intercalação entre ritmos binários e ternários é um procedimento recorrente na polifonia clássica palestriniana ${ }^{19}$. Missa In honorem beati Ambrosii (compassos 4/4 [Moderato] - 3/2 [Più mosso] - 3/2 [Com vita]); 2) na Missa In honorem S.S. Gervasii et Protasii (compassos 2/2 [Andante] - 3/2 - 2/2). Ocorre igualmente em quase todas as Missas a duas vozes de Fr. Sinzig: Missas Zu Ehren des hl. Antonius (compassos 4/4 [Andante] - 3/4 [Expressivo] - 4/4 [Con moto]), Festiva (3/4 [Moderato] - 4/4 [Andante] - 3/4 [Con moto]), Jubilate (compassos 4/4 [Andantino] - 3/4 - 4/4), Rosa mistica (compassos 4/4 [Andante] - 3/4 [Con moto] - 4/4). Percebe-se, pois, que a forma A-B-A em termos rítmicos é algo comum na composição de Kyries cecilianistas.
}

19 Alguns autores destacam, por exemplo, o uso mais intensivo que Tomás Luis de Victoria (1548-1611) fazia desta dinâmica binário/ ternário em suas peças polifônicas quando comparado a Palestrina (Cf. REESE, 2006; STEVENSON, 1993). 
Quanto às figuras rítmicas ${ }^{20}$ utilizadas, verifica-se que aproximadamente metade (47\% na Voz 1 e 62\% na Voz 2) dos valores de duração musical empregados por Nepomuceno no Kyrie correspondem à unidade de tempo dos compassos empregados (3/4 e 4/4). A figura de menor valor corresponde à colcheia, metade do valor da unidade de tempo. Estes dados, unidos ao andamento indicado pelo compositor, denotam o caráter grave que se esperava das composições sacras e, ao mesmo tempo, a ausência de grandes contrastes de velocidade nas linhas melódicas vocais (Tab. 7).

\begin{tabular}{|c|c|c|}
\hline Figuras rítmicas & Voz $1 \mathrm{~V}$ & oz 2 \\
\hline Colcheia & 16 & 5 \\
\hline Semínima & 40 & 39 \\
\hline Semínima pontuada2 & & 1 \\
\hline Mínima & 15 & 10 \\
\hline Mínima pontuada1 & 27 & \\
\hline Semibreve1 & & - \\
\hline TOTAL: & 86 & 62 \\
\hline
\end{tabular}

Tab. 7 - Nepomuceno: quantidade de figuras rítmicas no Kyrie (O autor).

Do ponto de vista da tessitura vocal empregada por Nepomuceno no Kyrie, verifica-se que o compositor não se propõe a explorar os limites da voz e opta por um âmbito de altura bastante restrito, o que novamente aproxima-o do ideal de música eclesiástica da época, que deliberadamente evita determinados efeitos caracteristicamente operísticos da escrita vocal (Tab. 8).

\begin{tabular}{|l|l|l|}
\hline & Voz 1V & oz 2 \\
\hline Nota mais grave & Mi 3 & Lá 2 \\
\hline Nota mais aguda & Mi 4 & Ré 3 \\
\hline
\end{tabular}

Tab. 8 - Nepomuceno: tessitura vocal no Kyrie (O autor).

Comparando-se com as extensões comumente utilizadas para a escrita vocal, conclui-se que a gama de sons empregados por Nepomuceno enquadram a Voz 1 e a Voz 2 de sua Missa respectivamente como soprano e contralto (Fig. 39).

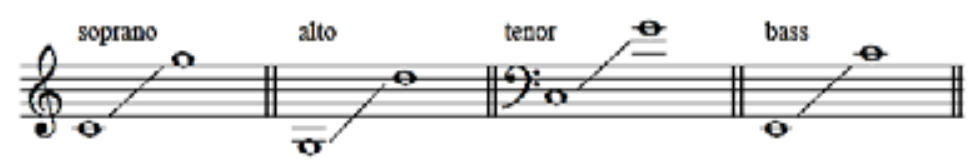

Fig. 39 - Extensões das vozes em escrita coral (KOSTKA; PAYNE; ALMÉN, 2013, p. 72).

\footnotetext{
20 LaRue sugere que no nível das pequenas dimensões musicais leve-se em conta, para fins de análise estilística, as relações de duração entre as figuras rítmicas empregadas pelo compositor em uma obra: "Podemos criar uma tipologia de modelos ordenados, em primeiro lugar, segundo seus tamanhos, por exemplo, segundo a acumulação de suas durações e, em segundo lugar, conforme suas formações, levando em conta sobretudo seu grau de contraste, que afeta poderosamente nosso sentido de movimento. Dentro de um pulso constante do continuum, por exemplo, de semínimas, pode originar-se um claro crescendo rítmico a partir de progressões tais como estas: um par de colcheias, colcheia e duas semicolcheias, colcheia pontuada etc. 0 grau de contraste eleva-se de 1:1 até 1:4" (p. 1989, p. 87, tradução nossa).
} 
Quanto aos intervalos melódicos utilizados ${ }^{21}$, notam-se dois fatos relevantes para uma análise estilística: 1) o amplo predomínio do movimento por grau conjunto (101 dos 122 intervalos melódicos utilizados, ou seja, 83\%) e 2) os saltos melódicos restritos a terças, quartas, quintas e oitavas justas (Tab. 9). Nota-se, assim, como o compositor opta por uma gama de intervalos idêntica àquela própria da construção de linhas melódicas do cantochão e do contraponto palestriniano. De fato, no canto gregoriano utilizam-se somente segunda maior ou menor, terça maior ou menor, quarta justa, quinta justa e raramente emprega-se a sexta. Os intervalos aumentados e diminuídos são proscritos (ROSE, 1963, p. 165). E em Palestrina:

O material melódico de Palestrina é [...] relativamente limitado. Somente os seguintes intervalos são ordinariamente utilizados: as segundas e terças maiores e menores, a quarta justa, a quinta justa, a sexta menor (somente ascendente) e a oitava. [...] Considerados em conjunto, os intervalos empregados por Palestrina são idênticos aos do cantochão, somente tendo sido acrescidos à música polifônica a sexta menor ascendente e a oitava. (JEPPESEN, 2005, p. 52, tradução nossa).

\begin{tabular}{|c|c|c|}
\hline & Voz $1 \mathrm{~V}$ & oz 2 \\
\hline Uníssono & 56 & \\
\hline $2^{\mathrm{a}} \mathrm{m}$ asc. 5 & & 4 \\
\hline $2^{\mathrm{a}} \mathrm{m}$ desc. & 11 & 8 \\
\hline $2^{\mathrm{a}} \mathrm{M}$ asc. 1 & 51 & 0 \\
\hline $2^{\mathrm{a}} \mathrm{M}$ desc. & 22 & 15 \\
\hline $3^{\mathrm{a}} \mathrm{m}$ asc. 2 & & \\
\hline $3^{\mathrm{a}} \mathrm{m}$ desc. & 2 & \\
\hline $3^{\mathrm{a}} \mathrm{M}$ asc. 1 & & \\
\hline $3^{\mathrm{a}} \mathrm{M}$ desc. & 22 & 2 \\
\hline $4^{\mathrm{a}} \mathrm{j}$ asc. 5 & & 1 \\
\hline $4^{\mathrm{a}} \mathrm{j}$ desc. & & \\
\hline $5^{\mathrm{a}} \mathrm{j}$ desc. & 2 & \\
\hline $8^{\mathrm{a}} \mathrm{j}$ desc. & 1 & \\
\hline & 73 & \\
\hline
\end{tabular}

Tab. 9 - Nepomuceno: quantidade de intervalos melódicos no Kyrie(O autor).

Do ponto de vista da dinâmica e do timbre, tanto o Kyrie, em particular, como a Missa, em geral, não apresentam grandes sutilezas, isto é, especificações detalhadas de controle de dinâmica. A textura a duas vozes iguais e o órgão como instrumento exclusivo de acompanhamento obviamente limitam as possibilidades de intensidade e de

\footnotetext{
21 LaRue aponta como relevante à análise musical estilística a consideração dos tipos de intervalos melódicos recorrentes em uma obra: "Ainda que uma tipologia da pequena dimensão deva considerar os intervalos, será conveniente colocá-los em agrupamentos funcionais, como a dicotomia convencional entre graus conjuntos e disjuntos, à qual se deveria acrescentar, por motivos de análise estilística, outra categorias que nos seria muito útil: os saltos. [...] Os três grupos de ações mencionadas (graus conjuntos, disjuntos e saltos) poderão definir praticamente qualquer estilo melódico, se pensarmos neles com flexibilidade, considerando-os como movimentos melódicos relativamente pequenos, médios e grandes, respectivamente" (1989, p. 63-64, tradução nossa).
} 
cor. As marcações para órgão restringem-se a indicações iniciais para registros. Para o Coro, restringem-se a algumas relações de contrastes forte-piano ou à marcação intermediária mezzo forte. Digno de nota é a indicação de piano para toda a segunda seção, Christe eleison, que, aliado à textura solista e à mudança de compasso e de andamento, explicita o caráter diferenciado que o compositor quis conferir a tal trecho e, consequentemente, a clara divisão formal que imprimiu à obra.

Quanto à estrutura rítmico-prosódica do Kyrie de Nepomuceno, verifica-se que há uma aproximação ao tratamento que o cantochão e a polifonia palestriniana procuram dar ao texto. Trata-se, basicamente, de 1) atribuir à sílaba tônica da palavra latina a nota mais aguda do perfil melódico (ou ao menos mais aguda que as notas atribuídas às silabas seguintes na mesma palavra), quando se trata de uma declamação silábica, ou de 2) atribuir à sílaba tônica da palavra latina um número maior de notas do que as notas atribuídas às silabas seguintes, quando se trata de uma declamação não silábica (neumática ou melismática, no canto gregoriano). E, de fato, verifica-se que as diferentes linhas melódicas de Nepomuceno se adequam quase que perfeitamente a estas duas regras: geralmente são nas notas atribuídas à sílaba $K Y ́$ ou CHRÍS em Kýrie e Chríste e à sílaba $L E ́ l$ de eleison que o compositor coloca como ponto culminante agudo do perfil melódico ou como grupo de notas em uma declamação não silábica do texto. Pode ocorrer também que o destaque à sílaba tônica não se dê no aspecto melódico, mas sim no rítmico, por meio de, por exemplo, uma maior duração conferida à nota que carrega a referida sílaba (Tab. 10). 


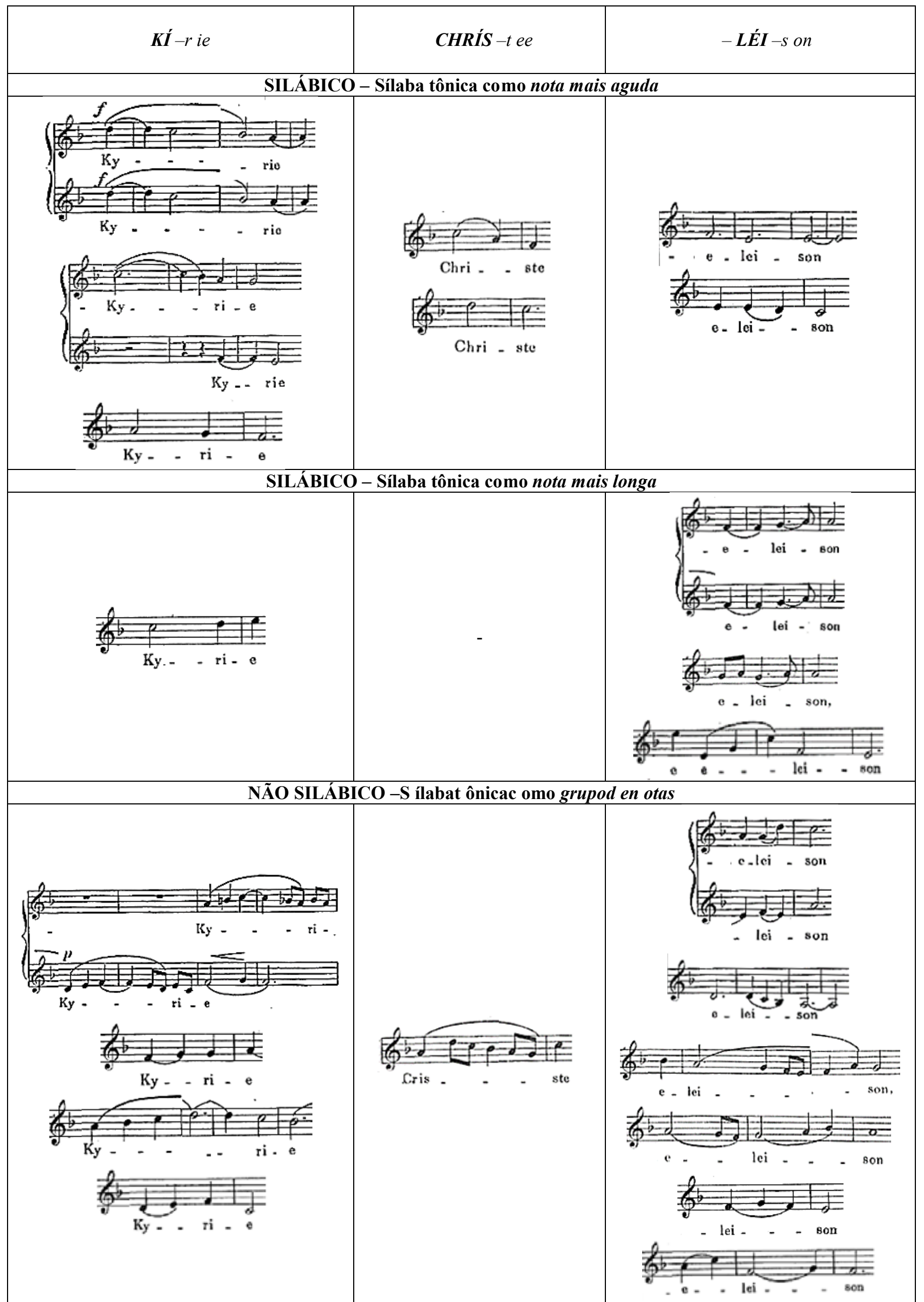




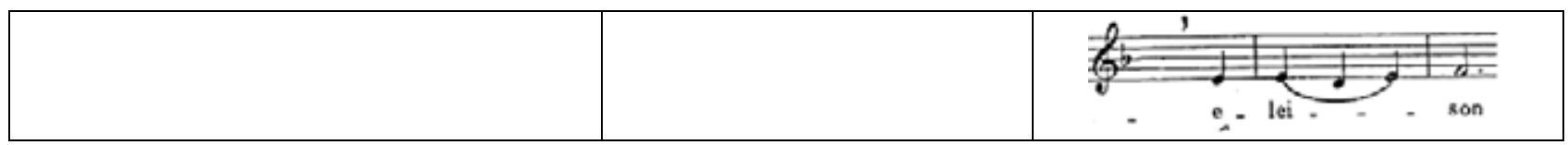

Tab. 10 - Nepomuceno: Prosódia latina no Kyrie (O autor).

\section{Conclusão}

Assim, pois, a partir da análise do Kyrie da Missa de Alberto Nepomuceno no que concerne a diferentes parâmetros musicais, a saber, intertextualidade, estrutura harmônica, configuração melódica e prosódica, apresentamos algumas conclusões que se impuseram. Utilizaremos, para tanto, uma das nomenclaturas utilizadas em estudos na área de intertextualidade musical ${ }^{22}$.

No que tange à forma do Kyrie de Nepomuceno, verificou-se que a distinção das seções se fundamenta na tríplice divisão do texto (Kyrie eleison - Christe eleison - Kyrie eleison) e na correspondente articulação de diferentes texturas vocais (solo x coro, uníssono $\mathrm{x}$ homofonia etc.), método esse, aliás, comum na música sacra polifônica. Digno de nota, contudo, é o fato de que a estrutura que Nepomuceno utiliza, assim como a instrumentação e a textura a duas vozes, é semelhante à do Kyrie da Missa Te Deum laudamus de Lorenzo Perosi. Considerando-se que a hipótese de uma possível influência direta desta obra em Nepomuceno foi já levantada ${ }^{23}$, parece-nos conveniente considerar este procedimento compositivo de Nepomuceno como uma citação de esquema formal.

No que tange ao tema introdutório para solo de órgão, recorrente em todas as unidades funcionais da Missa, com exceção do Sanctus, nota-se uma proximidade estilística do tipo de construção melódica do cantochão gregoriano, particularmente no Modo I (Ré). Verificou-se uma semelhança da melodia de Nepomuceno com vários exemplos do repertório gregoriano tradicional. Contudo, como se trata de uma melodia original de Nepomuceno, e não de uma citação textual, pode-se considerar tal procedimento de Nepomuceno como uma citação estilística ou sintética. Na verdade, o inciso final da primeira frase cantada (o primeiro Kyrie eleison, em uníssono) parece-nos que pode ser considerado uma citação com intenção referencial, já que é um elemento melódico tão recorrente nos Kyries gregorianos, que a hipótese de uma citação deliberadamente literal aqui não deve ser desprezada.

A análise também aproximou esta decisão de Nepomuceno a alguns exemplos da música sacra e religiosa de Liszt, que também se valeu, por exemplo, na abertura de seu Oratório Christus, de uma melodia gregoriana (neste caso, uma citação literal), tornando de certa forma o perfil melódico de sabor gregoriano um símbolo de caráter musical religioso.

\footnotetext{
22 Corrado (1992) distingue na Música duas grandes áreas no que tange à intertextualidade: 1) área intrassemiótica - contém os fatos produzidos com meios estritamente musicais; e 2) área intersemiótica - reúne fenômenos derivados de relações com outros discursos (linguagem verbal, imagem etc.). Para a área intrassemiótica, aponta três possibilidades: 1) citação de materiais geradores ou de esquemas formais (ex: missas ou motetos medievais construídos a partir de um cantus firmus); 2) citação estilistica, falsa citação ou citação sintética: consiste na reconstituição de gestos formais e expressivos dominantes de um estilo, mas sem referência a uma obra em particular, com diferentes graus de fidelidade (ex: paródia estilística, pastiche, neoclassicismo do início do século XX etc.); e 3) citação textual: consiste na incorporação de materiais temáticos reconhecíveis (melodias ou complexos polifônicos) tomados de uma determinada obra preexistente.
} 
Essa semelhança, em termos temáticos/melódicos do Kyrie de Nepomuceno com o perfil melódico gregoriano, também pôde ser percebida em alguns trechos vocais da obra. Parece-nos que, assim, o compositor se alinhava a uma das diretrizes que a própria Igreja dá às novas composições musicais litúrgicas: "uma composição religiosa será tanto mais sacra e litúrgica quanto mais se aproxima no andamento, inspiração e sabor da melodia gregoriana, e será tanto menos digna do templo quanto mais se afastar daquele modelo supremo" (PIO X, 1903). Este sabor da melodia gregoriana no Kyrie de Nepomuceno evidencia-se não só pela estrita construção musical, mas também pela aderência ao texto sacro. Com efeito, verificou-se que o compositor seguiu quase que à risca a prosódia latina, isto é, fez coincidir os pontos mais agudos ou mais ornamentados de suas melodias com as sílabas acentuadas do texto litúrgico.

Finalmente, no que se refere ao parâmetro harmonia, verificou-se pela análise que Nepomuceno não se atém à chamada prática comum, isto é, ao conceito de tonalidade unificada (LARUE, 1989, p. 44-45) em que há uma hierarquia funcional de acordes em torno de uma tônica, com clara direcionalidade (tensão/resolução). No Kyrie de Nepomuceno nota-se a presença do que se poderia chamar neomodalidade, uma vez que o compositor utiliza a gama de acordes da tonalidade supostamente principal - Ré menor - e sua relativa maior, mas evita deliberadamente as cadências fortes e o uso da sensível, produzindo, assim, um efeito que explora o colorido harmônico próprio das antigas progressões modais (Ibidem). De nossa parte, procuramos também mostrar que este caráter modal parece que se deve, em parte, a algumas técnicas de harmonização do canto gregoriano, segundo as quais devem ser privilegiados os acordes formados sobre os graus que melhor caracterizam os antigos modos. Mostramos também que tal concepção de acompanhamento do cantochão era compartilhado por importantes compositores de música sacra da época, tais como Liszt e Perosi.

Procuramos, enfim, lançar uma nova luz sobre uma parte do repertório erudito brasileiro ainda não devidamente explorado, a saber, a música sacra e religiosa da primeira metade do século XX, mostrando possíveis proximidades estilísticas com determinados paradigmas estéticos então em voga no movimento de restauração da música litúrgica tradicional católica.

\section{REFERÊNCIAS}

Livros, teses e artigos:

ASENSIO, J. C. El canto gregoriano: Historia, liturgia, formas. Madrid: Alianza, 2016.

BAS, J. Tratado de la forma musical. Bueno Aires: Ricordi, 1947.

BOULENGER. Doutrina católica: Manual de instrução religiosa para uso dos Ginásios, Colégios e Catequistas voluntários. V. 3: Meios de santificação e Liturgia. São Paulo: Francisco Alves, 1949. 
BURKHOLDER, J. Peter. INTERTEXTUALITY. In: The New Grove Dictionary of Music and Musicians. London: Macmillan, 2001. Disponivel em: <http://www.oxfordmusiconline. $\mathrm{com} /$ subscriber/article/grove/music/52853?q=intertextuality\&search=quick\&source=omo_gmo\&pos=18_start=1\#firsthit $>$. Acesso em: 10 jul. 2016.

CASTAGNA, P. Níveis de organização na música católica dos séculos XVIII e XIX. I Colóquio Brasileiro de Arquivologia e Edição Musical. Mariana: Coordenadoria de Cultura e Artes da UNI-BH, Secretaria de Estado da Cultura de Minas Gerais, Fundação Cultural e Educacional da Arquidiocese de Mariana, 2004.

CIAMPA, L. Don Lorenzo Perosi. Bloomington: AuthorHouse, 2006.

CORRADO, O. Posibilidades intertextuales del dispositivo musical. In: CORRADO, O.; KREICHMAN, R.; MALACHEVSKY, J. (Eds.). Migraciones de sentidos: tres enfoques sobre lo intertextual. Santa Fe: Universidad Nacional del Litoral, Centro de Publicaciones, 1992. p. 33-51.

CORRÊA, S. A. Alberto Nepomuceno; catálogo geral. 2. ed. Rio de Janeiro: Funarte/Coordenação de Música, 1996.

FERRETTI, P. Estetica gregoriana: trattato dele forme musicali del canto gregoriano. Roma: Pontificio Instituto di Musica Sacra, 1934.

GOLDBERG, L. G. Alberto Nepomuceno e a Missa de Santa Cecília. Anais do VI Encontro de Musicologia Histórica. Juiz de Fora, p. 146-172, 2006.

JEPPESEN, K. The style of Palestrina and the dissonance. New York: Dover Music, 2005.

KOSTKA, S.; PAYNE, D.; ALMÉN, B. Tonal Harmony: with na Introduction to Twentieth-Century Music. 7. ed. New York: McGraw-Hill, 2013.

LARUE, J. Análisis del estilo musical: pautas sobre la contribución a la música del sonido, la armonía, la melodía, el ritmo y el crecimiento formal. Barcelona: Labor, 1989.

Liber Usualis. Tournai: Desclée Company, 1961.

MERRICK, P. Revolution and Religion in the Music of Liszt. Cambridge: Cambridge University Press, 2008.

MEYER, L. Style and Music: Theory, History and Ideology. Chicago: University of Chicago Press, 1996.

MILLS, B. A. Psallite sapienter: A Musician's Practice Guide to the 1962 Roman Missal. 
Richmond: Church Music Association of America, 2008.

NIEDERMEYER, L.; D'ORTIGUE, J. Gregorian Accompaniment: A Theoretical and Practical Treatise upon the Accompaniment of Plainsong. London: Novello, Ewer \& Co., 1905.

PIO X. Motu Proprio Tra le sollicitude do Sumo Pontífice Pio $X$ sobre a música sacra. 1903. Disponível em: <http://w2.vatican.va/content/pius-x/pt/motu_proprio/documents/hf_p-x_motu-proprio_19031122_sollecitudini.html>.

REESE, G. La musica en el Renacimiento. V. 2. Madrid: Alianza Música, 2006.

REUS, J. B. Curso de Liturgia. Petrópolis, RJ: Vozes, 1944.

ROSE, M. Canto gregoriano: método de Solesmes. Rio de Janeiro, 1963.

STEVENSON, R. La música en las catedrales españolas del Siglo de Oro. Madrid: Alianza, 1993.

Suma teológica de São Tomás de Aquino. Disponível em: <http://permanencia.org.br/ drupal/node/8>.

TEIXEIRA, T. P.; DUDEQUE, N. O Sanctus de Alberto Nepomuceno: um caso de intertextualidade musical. Musica Theorica, Salvador: TeMA, p. 1-28, dez. 2017.

Terceiro catecismo da doutrina cristã. Petrópolis, RJ: Vozes, 1937.

Periódicos:

O Paiz, Rio de Janeiro, 27 out. 1915.

Partituras:

LISZT, F. Missa Choralis [Musikalische Werke. Serie V, Band 3]. Leipzig: Breitkopf \& Härtel, 1918. Plate F.L. v 4. Partitura. Coro misto e órgão.

LISZT, F. Te Deum II [Musikalische Werke. Serie V, Band 7]. Leipzig: Breitkopf \& Härtel, 1936. Plate F.L. v 65. p. 173-182. Partitura. Coro misto, órgão, 2 trompas, 2 trompetes, 2 trombones, Tímpanos ad lib.

NEPOMUCENO, A. Missa: duabus vocibus aequalibus quam in honorem Virginis Immaculatae concinnavit et eminentíssimo Domino Cardinali Arcoverde dicavit. Rio de Janeiro: E. Bevilacqua \& C., [s.d.]. Partitura. Coro e órgão. 
NEPOMUCENO, A. Sinos de Natal. Manuscrito autógrafo. (4 p). Partitura. Piano.

PEROSI, L. Missa De Beata: col proprio della Messa "Puer" secondo la lezione dei Codici, com accompagnamento ed interludi d'organo, dedicata ai Seminaristi d'Italia. Milão: A. Bertarelli, [s.d.]. Partitura.

PEROSI, L. Missa Pontificalis. Milão: Ricordi, 1899. Partitura. Coro misto a 3 vozes e órgão.

PEROSI, L. Missa Te Deum laudamus. Milão: Ricordi, 1899. Partitura. Coro misto a 2 vozes e órgão. 